\title{
Individualização, cidadania e inclusão na sociedade contemporânea uma análise teórica
}

\author{
Maria Izabel Sanches Costa \\ Aurea Maria Zöllner lanni
}

\section{SciELO Books / SciELO Livros / SciELO Libros}

COSTA, M.I.S., and IANNI, A.M.Z. Individualização, cidadania e inclusão na sociedade contemporânea: uma análise teórica [online]. São Bernardo do Campo, SP: Editora UFABC, 2018, 122 p. ISBN: 978-85-68576-95-3. https://doi.org/10.7476/9788568576953.

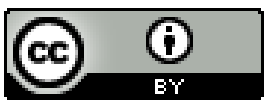

All the contents of this work, except where otherwise noted, is licensed under a Creative Commons Attribution 4.0 International license.

Todo o conteúdo deste trabalho, exceto quando houver ressalva, é publicado sob a licença Creative Commons Atribição 4.0.

Todo el contenido de esta obra, excepto donde se indique lo contrario, está bajo licencia de la licencia $\underline{\text { Creative }}$ Commons Reconocimento 4.0 . 


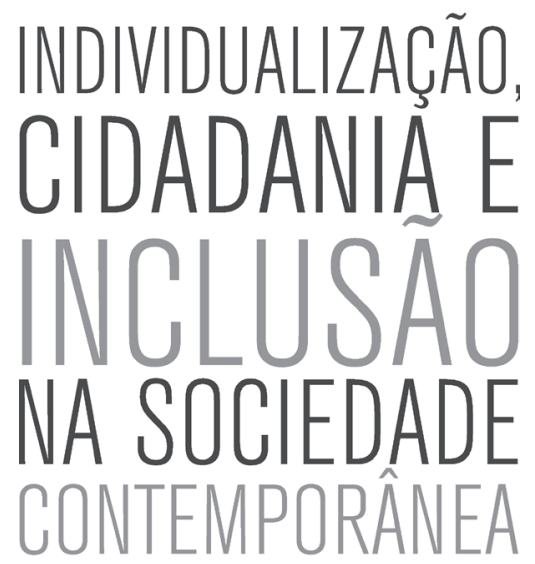

uma análise teórica 


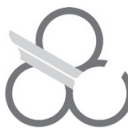 \\ UFABC}

\section{UNIVERSIDADE FEDERAL DO ABC}

Klaus Werner Capelle - Reitor

Dácio Roberto Matheus - Vice-Reitor

\section{Editora da UFABC}

Fernando Costa Mattos - Coordenador

Christiane Bertachini Lombello - Vice-Coordenadora

Conselho Editorial

Ana Claudia Polato e Fava

Ana Paula de Mattos Arêas Dau

Andrea Paula dos Santos Oliveira Kamensky

Artur Zimerman

Christiane Bertachini Lombello

Daniel Pansarelli

Daniel Zanetti de Florio

Fernando Luiz Cássio Silva

João Rodrigo Santos da Silva

Júlio Francisco Blumetti Facó

Luciana Pereira

Marcelo Augusto Leigui de Oliveira

Márcia Helena Alvim

Margarethe Born Steinberger-Elias

Sidney Jard da Silva

Sílvia Dotta

Equipe Técnica

Cleiton Klechen

Natalia Gea 
MARIA IZABEL SANCHES COSTA AUREA MARIA ZÖLLNER IANNI

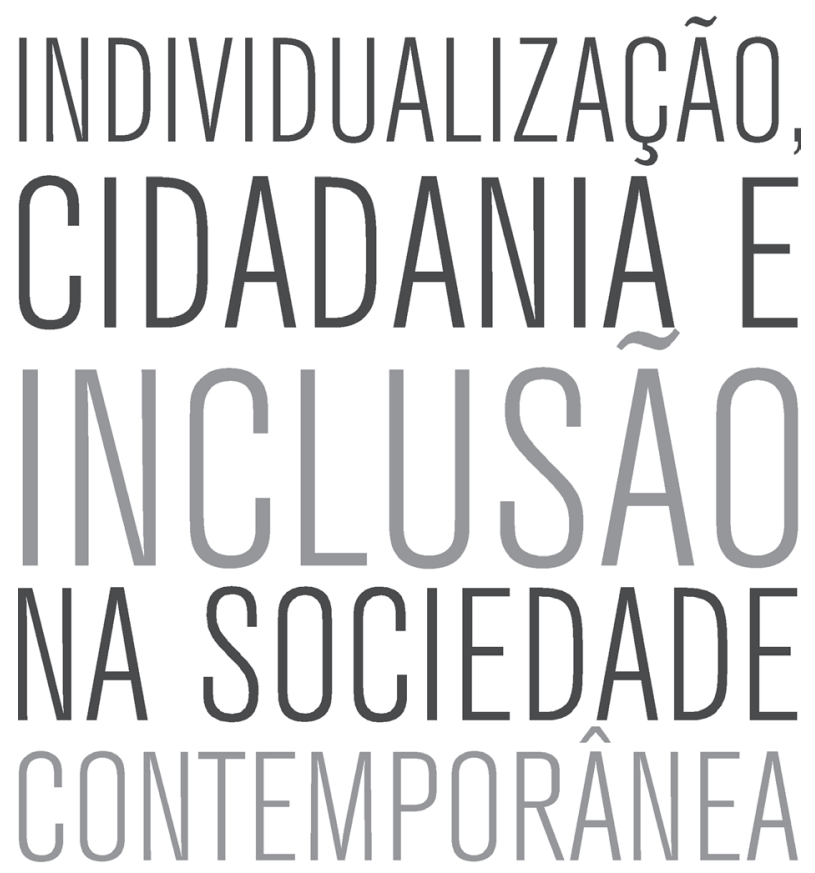

u ma análise teórica

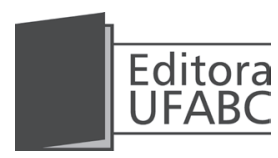

São Bernardo do Campo - SP 2018 
(C) Copyright by Editora da Universidade Federal do ABC (EdUFABC)

Todos os direitos reservados.

\title{
Equipe Técnica sob Coordenação da Gráfica e Editora Copiart
}

\author{
Revisão \\ Bianca Santos \\ Diagramação e capa \\ Rita Motta \\ Impressão \\ Gráfica e Editora Copiart
}

CATALOGAÇÃO NA FONTE

SISTEMA DE BIBLIOTECAS DA UNIVERSIDADE FEDERAL DO ABC

Costa, Maria Izabel Sanches

Individualização, cidadania e inclusão na sociedade contemporânea: uma análise teórica / Maria Izabel Sanches Costa, Aurea Maria Zöllner lanni — São Bernardo do Campo, SP : EdUFABC, 2018.

xii, 122 p.

ISBN: 978-85-68576-86-1

1. Individualismo. 2. Cidadania. 3. Inclusão Social. 4. Identidade Social. 5. Sociedade - Século XXI. 6. Direitos Humanos. I. Ianni, Aurea Maria Zöllner. II. Título.

CDD 22 ed. -323.3

EDITORA ASSOCIADA

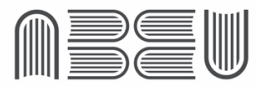

Associação Brasileira das Editoras Universitárias 


\section{PREFÁCOO}

Qivro que o leitor tem em mãos parte de um pressuposto
principal: estamos mergulhados em um momento histórico, caracterizado por mudança, por crise, por transição. Já não vivemos mais como nossos pais. Tudo o que parecia sólido está em plena transfiguração, dos relacionamentos e da organização da família ao modo como governa-se e organiza-se o Estado, da estruturação da dinâmica social às formas da política, dos estilos de pensamento teórico aos critérios que balizam a produção cultural. Vivemos em um momento no qual se modificam os paradigmas que, por mais de um século, orientaram os grupos e os indivíduos, em um ciclo que se costuma associar ao conceito de modernidade histórica.

Como seria de esperar, conceitos e perspectivas teóricas ficaram problematizados, como se estivessem a perder força explicativa e necessitassem de reformulação. Alguns chegaram mesmo a ser desidratados pelos debates contemporâneos, como seria o caso, para usar exemplos cômodos, dos conceitos de família, nação e Estado. Ainda que não devam e não possam ser descartados como se pertencessem a outra galáxia - até porque são recursos coletivos com os quais a humanidade continua a reproduzir a vida -, eles passaram a exigir considerações analíticas e teóricas que ampliaram, em muito, o modo como eram até então pensados. 0 mesmo se poderia dizer dos conceitos de globalização e capitalismo. 
A ideia de que estaríamos a viver em uma época pós-moderna passou a ocupar importante espaço nas discussões, depois que foi posta em circulação no final dos anos 1970. Tornou-se usual dizer que a humanidade teria ingressado em um beco sem saída, no qual as grandes conquistas modernas - na sociabilidade, na economia, na política, na ciência, nas artes e na filosofia - teriam sido problematizadas. As perspectivas, as ferramentas e os princípios com que se buscava organizar o mundo, e sobretudo explicá-lo, estariam saturados e esgotados. A totalização (os discursos universais, as grandes narrativas) já não mais seria possível ou desejável.

Passado o primeiro momento, quando foi intenso o impacto das postulações pós-modernas e foi ainda mais intensa a reação defensiva dos que continuavam a demonstrar a consistência de suas convicções a partir das mesmas ideias de antes, o ambiente intelectual ingressou em uma fase mais cuidadosa e reflexiva.

Tornou-se gradualmente predominante a ideia de que não fazia sentido imaginar que a modernidade esgotara todo o seu potencial de formatação da vida e teria sido sumariamente superada por arranjos pós-modernos, que se reproduziriam sem contestação. Ganharam fôlego formulações de outro matiz, preocupadas em fundamentar a hipótese de que a modernidade, em vez de ter sido ultrapassada, enveredara por caminhos outros, no correr dos quais foi adquirindo novas forças e sendo turbinada de mil maneiras.

Passou-se, então, a falar em hipermodernidade, segunda modernidade, sociedade de risco, modernidade líquida, sociedade em rede e constelações pós-nacionais, expressões com as quais se buscou qualificar o processo 
que levou a modernidade a adquirir musculatura, a tornar-se superlativa e excessiva, a conviver com um capitalismo desenfreado e mundialmente dominante, produzindo efeitos contraditórios, intrigantes, difíceis de serem explicados de modo categórico. A ambivalência e a incerteza cresceram em decorrência do esgotamento relativo dos parâmetros disponíveis para agir-se no mundo e, também, pelo modo como o mundo se movimenta: freneticamente, fora de controle, sem padrões, sacudido por espasmos sucessivos de crise e transformação. A era que se constitui sob nossos olhos traz consigo sofrimento e oportunidades, medo e sensação de liberdade.

Formou-se, assim, uma escola informal de cientistas sociais dedicados a dar conta desse amplo, diferenciado e sinuoso processo de transformação social.

É com essa escola que Maria Izabel Sanches Costa, em seu doutorado orientado por Aurea Maria Zöllner Ianni, deseja dialogar para enfrentar o desafio a que se propôs, qual seja, o de analisar o processo de transformação que agita as sociedades dos nossos dias e, de algum modo, requalifica os conceitos com que se busca explicar a expressão atual dos fenômenos sociais. Seu propósito é alcançar um roteiro para decifrar o padrão vigente de relações sociais, o processo de individualização típico do contexto atual e as formas de exercício da cidadania e de inclusão social.

Para realizar tal projeto intelectual, meritório em si mesmo, o texto se aprofunda em reflexões que ajudam a entender o atual momento. Por um lado, passa em revista o conceito de cidadania, valendo-se para tanto da perspectiva da identidade, com que procura examinar de que maneira o cidadão dos nossos dias traduz a ideia de 
pertencimento, a exigência de participação política e a aquisição da consciência de ser portador de direitos e deveres. Por outro lado, busca verificar em que medida materializa-se, hoje, a superação dos processos de exclusão social, em um quadro no qual cresceu a vulnerabilidade social, impulsionada pelos processos conexos de fragmentação, precarização do trabalho, corrosão da sociabilidade primária e expansão dos estigmas.

O livro não pretende oferecer respostas acabadas ou categóricas para os complicados temas e problemas que se propõe a discutir. Sua sensibilidade e sua inteligência intelectual fazem com que valorize o reconhecimento de que a nossa é uma época de controvérsias e dificuldades analíticas, na qual parecem faltar conceitos e teorias abrangentes. A pesquisadora sabe que também navega em um mar de complexidade cujas águas estão convulsionadas tanto pelos efeitos da revolução digital e da globalização capitalista intensificada, quanto pelas múltiplas crises atuais.

A forma emergente de vida coletiva ainda é uma incógnita, mesmo que esteja sendo discutida e interrogada intensamente. 0 que perdemos e o que estamos a ganhar com ela? Quais suas determinações? Que processos sociais, políticos, econômicos e culturais prevalecem e comandam? Com que bagagem ideológica e teórica estamos ingressando nela? Se aceitarmos que as mudanças são imponentes e efetivamente alteram o modo como se vive, revolvendo suas bases e seus padrões, então, teremos de admitir que não é razoável continuar tentando explicar o mundo com as mesmas categorias e teorias de antes. Não precisamos abandonar o grandioso legado teórico da modernidade para reconhecer que vivemos numa profunda 
crise de paradigmas, que aparece nas mais diversas situações. Mas temos de aperfeiçoar e atualizar o modo como pedimos aos clássicos para auxiliar-nos. Nenhuma teoria pode hoje se apresentar como carregando consigo uma verdade explicativa completa.

Precisamente por isso, esforços intelectuais, como o que é feito no presente livro, são indispensáveis. Eles nos ajudam a encontrar uma melhor compreensão sobre a época em que vivemos e a desenhar os mapas cognitivos e políticos com que construir um futuro comum de justiça e inclusão social, democracia, emancipação e maior igualdade.

São Paulo, dezembro de 2016.

\section{Marco Aurélio Nogueira}

Coordenador Científico do Núcleo de Estudos e Análises Internacionais-NEAI Instituto de Políticas Públicas e Relações Internacionais Universidade Estadual Paulista-UNESP. 


\section{SUMÁRIO}

APRESENTAÇÃO........................................................................ 1

TRANSFORMAÇÕES DA SOCIEDADE

CONTEMPORÂNEA ................................................................. 5

O processo de individualização........................................ 8

Transformações sociopolíticas ..................................... 23

O CONCEITO DE CIDADANIA ................................................ 43

Sobre o conceito de cidadania e seu exercício na sociedade contemporânea ........................................ 47

Tipologia da cidadania .................................................... 70

A DIALÉTICA DO CONCEITO DE EXCLUSÃO/ INCLUSÃO SOCIAL ................................................................. 75

O conceito de exclusão social....................................... 84

Tipologia da exclusão social .......................................... 99

RETICÊNCIAS........................................................................ 103

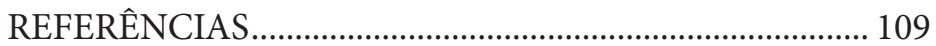




\section{APRESENTAÇÃOO}

Este livro se dedica à parte teórica da tese de doutorado Le Maria Izabel Sanches Costa, defendida em 2016 na Faculdade de Saúde Pública da Universidade de São Paulo (FSP-USP), sob a orientação da Professora Dra. Aurea Maria Zöllner Ianni cujo título é Saúde Mental e os Novos Paradigmas da Cidadania e Inclusão Social na Sociedade Contemporânea.

A coautoria do livro resulta do diálogo estabelecido ao longo dos quatro anos de desenvolvimento do doutorado, no qual o tema da desinstitucionalização dos sujeitos em sofrimento psíquico, questão central às políticas públicas de saúde, mais especificamente à de saúde mental, conformou-se como objeto de pesquisa, confrontado ao processo de individualização radicalizada da sociedade contemporânea.

Próxima ao tema da saúde mental e do sofrimento dos sujeitos institucionalizados em hospitais psiquiátricos desde a graduação, Maria Izabel Sanches Costa aproximou-se da questão da individualização no doutorado, em diálogo estabelecido com a linha de pesquisa de mudanças sociais contemporâneas e saúde, na qual se desenvolve o projeto Individualização no contexto das mudanças sociais contemporâneas: desafios para a Saúde 
pública/Coletiva no Brasil, financiado pela Fundação de Amparo à Pesquisa do Estado de São Paulo (FAPESP), sob a coordenação de Aurea Maria Zöllner Ianni.

Foi dessa aproximação temática e teórica que as categorias de inclusão social e cidadania, fortes marcadores da política de desinstitucionalização na saúde mental, ganhou relevância.

Ao assumir como hipótese da pesquisa que a saída do hospital psiquiátrico, por si só, não garante uma efetiva inclusão social nem o exercício da cidadania aos sujeitos em sofrimento psíquico, foi necessário realizar um estudo que possibilitasse construir um alinhamento conceitual que fundamentasse a análise do material empírico recolhido - legislação, artigos e relatórios de conferências da área de saúde. Essa atividade culminou com a construção de um conceito ideal - segundo Max Weber - tanto para cidadania, como para exclusão social, que subsidiou também, um diagnóstico sobre o impacto do processo de transformação da sociedade contemporânea, particularmente o de individualização na política de desinstitucionalização e reinserção social.

Neste livro, apresenta-se o processo de construção desse alinhamento conceitual, a construção dos conceitos ideais e a análise das transformações da sociedade contemporânea, mais especificamente, frente ao processo de individualização da atualidade social.

Cidadania e inclusão social comumente são compreendidas como categorias complementares e, em alguns textos, como sinônimos. São categorias utilizadas por diferentes campos de saberes: direito, ciências sociais, história, relações sociais, saúde, psicologia, dentre outros. Aparecem em vários trabalhos, textos e discursos (de acadêmicos, jornalistas, políticos, gestores públicos e 
sociedade civil) e, corriqueiramente, sem a preocupação em explicitar de forma precisa sua definição. Entende-se que tal imprecisão conceitual é uma decorrência do fato de que tais conceitos são historicamente situados e, portanto, sofrem alterações conforme seu contexto sócio político. Assim, utilizá-los de forma a-histórica torna seu significado descolado da realidade em que se pretende analisar.

Para o exame dessas categorias, parte-se de quatro pressupostos que estão intrinsecamente relacionados.

0 primeiro é aquele em que as categorias de cidadania e inclusão social, apesar de complementares, são distintas, ainda que os dois conceitos estejam ligados à noção de território. A cidadania está vinculada à categoria Estado, enquanto a inclusão social está mais vinculada à sociedade. Isso porque cidadania relaciona-se mais estritamente às dinâmicas da dimensão política e inclusão mais estritamente às dimensões das relações sociais. Logicamente, as barreiras não são fixas, visto que as dimensões políticas também ocorrem no seio social. Entretanto, para facilitar a compreensão das categoriais, radicalizaremos propositalmente tais separações.

O segundo pressuposto parte da necessidade de se compreender o contexto societário como parte intrínseca e fundamental das transformações do próprio Estado, bem como das modificações da relação entre ele e a sociedade. Analisar os modos de exercício de cidadania e os processos de inclusão/exclusão social implica analisar também as transformações no seio social e seus impactos nos modos de políticas.

0 terceiro pressuposto, intrinsecamente ligado ao segundo, é o de que as categorias de cidadania e inclusão social devem ser compreendidas dentro do seu contexto sócio histórico, pois são conceitos historicamente 
situados. Cidadania e inclusão social na Grécia antiga são a mesma do século XVIII? Cidadania e inclusão social no século XVIII são as mesmas dos dias atuais? Partimos do pressuposto de que não.

O quarto pressuposto é o de que, atualmente, estamos na transição de um momento histórico, assistindo às mudanças nos paradigmas modernos que, por mais de um século, guiaram a vida da sociedade ocidental. 0 momento histórico presente marca um período de rupturas com as cadeias institucionais que se opõem à liberdade e à autonomia do indivíduo.

Este livro está dividido em três capítulos. No primeiro, é analisado o processo de individualização por ter como pressupostos as alterações das relações sociais decorrentes de tal processo e, consequentemente, as formas de exercício da cidadania e inclusão social no contexto sócio histórico atual.

No segundo capítulo, define-se a categoria de cidadania como a identidade social política composta de três eixos: vínculo de pertencimento, participação política/coletiva e consciência de ser portador de direitos e deveres.

Por fim, no terceiro capítulo é analisado o conceito de inclusão social como processo de superação de exclusão social, qual seja, situação de vulnerabilidade, composta também de três eixos: precarização do trabalho, precarização da sociabilidade primária e estigma.

É importante deixar claro, finalmente, que não tenho a pretensão de esgotar o tema, até mesmo por considerar que tais conceitos são alterados pelas transformações sócio-político-econômicas. Pretendo, porém, contribuir para uma melhor compreensão de tais categorias.

Boa leitura! 


\section{TRANSFORMACÕES DA SOCIEDADE CONTEMPORANEA}

Este capítulo dedica-se a apresentar uma análise do Lprocesso de individualização e as decorrentes transformações sociopolíticas contemporâneas. Tal estudo subsidiará as análises das categorias de cidadania e inclusão social, já que se parte do pressuposto de que essas devem ser compreendidas dentro de seu contexto sócio-histórico.

Vários são os nomes atribuídos ao atual momento histórico: pós-modernidade (BAUMAN, 2001; LIPOVETSKY, 2005a; HARVEY, 1994); modernidade líquida (BAUMAN, 2001, 1999a); modernidade reflexiva (GIDDENS; BECK; LASH, 1997); sociedade de risco e segunda modernidade (BECK, 2011); hipermodernidade (LIPOVETSKY, 2004), dentre outros. Assim como Ianni (2013, p. 43-44), utilizaremos, aqui, o termo primeira modernidade para referirmos a

[...] modernidade tradicional, aquele momento histórico em que a sociedade industrial moderna se configura, ainda, com as características da plena industrialização, da crença na assertividade da ciência e da tecnologia como expressão de razão 
e do progresso, da constituição e hegemonia dos estados-nação e o modelo de família nuclear.

Por sociedade contemporânea compreendemos "[...] um desdobramento, em autorreferência, da tradição moderna industrial; a transformação da modernidade por dentro de si mesma [...] que, no entanto, não deixa de promover mudanças estruturais na centralidade das sociedades ocidentais" (IANNI, 2013, p. 43-44).

Para Bauman (1999a), duas são as características que fazem do atual momento uma modernidade distinta da precedente ou do momento primeiro da modernidade: 1) o declínio da antiga ilusão moderna; e 2) o individualismo. A primeira refere-se à antiga crença de que há um ideal de sociedade e de Estado a ser alcançado. Para o autor, a metáfora da humanidade moderna - da ilusão moderna - era a do jardineiro. 0 jardineiro, nesse contexto, acredita na ordem do mundo e sabe exatamente qual o tipo de planta que deve crescer ou não, garantindo, assim, a construção de seu arranjo ideal. Para tal, ele precisa destruir as ervas daninhas indesejadas, que poderão alterar esse arranjo. É do jardineiro que emergem as grandes utopias norteadoras da sociedade moderna. Existiria, para ele, um projeto social, um norte para onde a sociedade deveria caminhar. Essa ideia moderna era embasada na fé do progresso da sociedade, segundo a qual a grande utopia e, consequentemente, os grandes projetos coletivos perdem espaço para o imediatismo e para os projetos individuais.

A segunda característica do momento atual, intrinsecamente ligada à primeira, é o deslocamento da ênfase do projeto coletivo para o individual. Esse individualismo realoca o discurso político, antes focado nos coletivos 
tradicionais modernos, como identidades nacionais ou de classe, por exemplo, para o lugar dos direitos humanos. Isso significa que o atual enfoque passa a ser o discurso do direito de os indivíduos serem diferentes e de escolherem seus próprios modelos de felicidade e estilos de vida. Assim, para o autor, sob o ponto de vista da dinâmica social, o elemento integrador da coesão social moderna desmoronou-se, pois não há mais um projeto coletivo mobilizador.

Com uma linha de pensamento convergente com a de Bauman (1999a), Lyotard (2002) afirma que esse novo momento é a época em que as grandes narrativas perdem a credibilidade e a admiração dos indivíduos e, portanto, a capacidade de domínio das consciências. Tais são os enunciados que marcam a emergência de novos paradigmas na sociedade contemporânea: a incapacidade do Estado de provocar o engajamento das massas a partir de um sentimento nacionalista; as incertezas em virtude da contemplação dos cenários pós-guerra; a crise na crença dos discursos de pretensão a uma aplicabilidade universal. Com discurso que se aproxima ao de Lyotard (2002), Harvey (1994, p. 19) afirma que "[...] a fragmentação, a indeterminação e a intensa desconfiança de todos os discursos universais ou (para usar um termo favorito) totalizantes são o marco do pensamento pós-moderno".

Compreende-se, assim, de acordo com os autores citados anteriormente, que o momento histórico do pós-guerra redimensionou a credibilidade de que desfrutavam as metanarrativas, bem como das instituições que lhes davam suporte. Iniciou-se uma fase de desconfianças dos discursos universais e cresceram as incertezas perante o futuro. A partir dessa crise, intensificaram-se o individualismo e a crise dos absolutos, a relativização do agir e 
do pensamento ético, bem como acentuaram-se a dimensão do viver no presente e a escassez do engajamento em massa. Em consequência dessas transformações, os interesses e as trajetórias individuais suplantaram os coletivos (BECK, 2011; BAUMAN, 2001; LIPOVETSKY, 2005a).

\section{O PROCESSO DE INDIVIDUALIZAÇÃO}

A noção de indivíduo é profundamente histórica e nem sempre existiu com os significados que lhe atribuímos atualmente. Acredita-se que indivíduo é um termo eminentemente moderno, que remonta ao Iluminismo e à ideia da libertação pela razão (MATEUS, 2011). Até o fim da Idade Média, o homem encontrava-se submisso à coletividade em que estava inserido, às relações de tradição, aos costumes e a um papel previamente determinado pelo seu nascimento. A identidade do homem tradicional era claramente definida e fixa. A vida era organizada por instituições rígidas e coletivas.

No advento da modernidade, emergiu a noção de indivíduo e sua prevalência sobre a noção do coletivo, o que quer dizer que a ênfase iluminista sobre o homem autônomo e racional trouxe mudanças fundamentais ao entendimento do indivíduo e de sua relação com a tradição, a obediência e a sociedade.

Inerente à emancipação da razão, esteve a reivindicação da liberdade como espaço reservado à autodeterminação de cada indivíduo em face do Estado. De fato, a liberdade dos modernos é a liberdade de não interferência sobre a intimidade do indivíduo e a favor da satisfação da independência privada. Essa liberdade moderna acirrou a 
primazia do privado sobre o público e do individual sobre o coletivo. Ela é alicerçada na emancipação do indivíduo sobre o social.

Bauman (2001, p. 39) ressalta que "[...] a apresentação dos membros como indivíduos é a marca registrada da sociedade moderna". É somente com a modernidade que a ideia de liberdade individual ganha ênfase.

É importante frisar que há uma diferença entre a individualização da primeira modernidade e a da sociedade contemporânea. Se a individualização dos séculos XVIII e XIX tinha como ideal a liberdade e a igualdade, a individualização que emergiu na segunda metade do século XX tem como ideal a distinção e a diferença. Esta evidencia que, na primeira modernidade, a igualdade ainda era um valor tão ou mais importante que a liberdade, ou seja, a individualização, apesar de importante, era algo secundário. Como Bauman (1999a) demonstra, a primeira modernidade foi marcada por um esforço de eliminação da ambivalência e de qualquer coisa que pudesse causar alguma desordem e atrapalhar a busca por uma sociedade planejada e ordenada, o que tornava qualquer diferenciação um tanto perigosa.

Os Estados nacionais modernos possuíam certa exigência de homogeneidade interna das identidades, constrangendo e até mesmo impedindo a proliferação da individualidade como ideário de distinção. No entanto, os indivíduos eram entendidos como livres e iguais, podendo exercer direitos e deveres perante a sociedade e o Estado, bem como sendo responsabilizados por suas ações. Além disso, sua identidade era previamente determinada por sua nacionalidade, gênero, classe social, profissão e família. 
Beck (2011) diz que, com o advento da modernidade, introduziu-se um modelo de individualização tripla: 1. desprendimento das formações e dos vínculos sociais estabelecidos historicamente; 2. perda das seguranças tradicionais; e, por último, 3. aparecimento de uma nova forma de enquadramento social, como resultado das anteriores. Isso quer dizer que, no processo de desenvolvimento político-econômico, no contexto da passagem da primeira modernidade para a chamada segunda modernidade (ou sociedade contemporânea), os indivíduos são libertados das formas sociais típicas da sociedade industrial, tais como os estratos e as classes sociais, a família, o gênero etc.

Com efeito, começa-se a desenhar uma concepção de indivíduo alicerçada na formulação de liberdade que visa ao alcance das condições necessárias para a construção de um projeto de vida próprio, individualizado, com opções de escolhas, possibilidades e decisões que só podem ser tomadas por si mesmo. De acordo com o autor, esse processo significa que o indivíduo, como agente de ação, pode definir suas formas de vida individuais, e coletivas e, portanto, tornar-se expressão das suas próprias escolhas, despregando-se, mais e mais, das amarras das formas sociais coletivas tradicionais modernas.

Com uma linha de raciocínio similar à de Beck (1997), Giddens (1997) entende que a biografia do indivíduo contemporâneo é um constructum formado de um continuum, caminho percorrido e a ser percorrido.

Dessa forma, pode-se concluir que a biografia individual é apresentada, para ambos os autores, como um projeto reflexivo, um conjunto aberto de possibilidades que requerem decisões constantes do indivíduo. 
De acordo com Beck (1997), o processo de individualização deve ser entendido no âmbito dos processos de formação e constituição social, no qual o indivíduo passa a ser a referência central das ações do mundo social. Isso faz com que a percepção sobre os mecanismos e os processos sociais em geral - no contexto de individualização - sejam vistos como problemas individuais e, portanto, como se não mais estabelecidos no domínio do social. Dessa forma, assiste-se a uma decomposição das fontes de significados coletivos, que se tornam objeto de desencantamento e até mesmo de esgotamento. Tal processo conduz as instituições sociais a redefinirem as suas funções de suporte, que agora se deslocam dos grandes coletivos para os indivíduos. Isso contribui para a perda da dimensão de coletivo (BECK, 2010).

Beck (1997) considera que, quando a modernidade atinge certo nível do seu desenvolvimento, diminuem os constrangimentos das regulações estruturais sobre os indivíduos, visto que as próprias forças do processo de mudança tornam os indivíduos mais livres em relação às estruturas modernas.

Estruturada no contexto da individualização, Beck (1997) refere-se à uma mudança estrutural da vida privada, que força os indivíduos a construírem reflexivamente sua própria biografia, isto é, a tomarem as suas próprias decisões, livres de pressões estruturais.

A individualização é uma compulsão, mas uma compulsão pela fabricação, o autoprojeto e a auto-representação, não apenas pela autobiografia, mas também de seus compromissos e articulações à medida que as fases da vida mudam [...] (BECK, 1997, p. 26). 
Nas análises de Beck (1997; 2000) e Giddens (1997), a reflexividade é um conceito central e diz respeito à capacidade de os indivíduos compreenderem os acontecimentos que se passam à sua volta, de tal modo que possam relacioná-los às suas atividades naquele momento, bem como reordenar suas atividades pelo uso dessas informações. Ações reflexivas podem estar no exame e nas transformações de práticas sociais, por força de informações novas. De acordo com Giddens (1991), a sociedade moderna tornou-se crescentemente reflexiva, período marcado pela suscetível revisão de todas as atividades sociais sob a luz de novas informações e conhecimentos, o que pode ser caracterizado como um monitoramento das atividades humanas.

Com base nas teorias dos autores mencionados, pode-se concluir que todos os aspectos da vida - das práticas sociais às instituições, do associativismo à construção do eu - passam a ser construídos reflexivamente.

A modernidade reflexiva - termo utilizado pelos autores para referir a dinâmica intrínseca da sociedade moderna - vai ocupar-se, sempre e mais, em dominar e controlar os problemas autocriados, ou seja, a reflexividade significa ocupar-se com problemas e consequências do próprio processo de transformação da sociedade. Em consequência disso, as construções reflexivas implicam um processo de questionamento, de dúvidas e de escolhas. Como não há mais estruturas fixas e permanentes - sólidas, como as denominaria Bauman (2001) -, tudo está em constante construção e desconstrução. A movimentação e a agitação fazem-se sentir em todas as esferas da vida, e o indivíduo é chamado constantemente a opinar, participar, escolher e decidir sobre os mais variados assuntos.

Enquanto Beck (1997) e Giddens (1991), ao analisarem a modernização reflexiva, relacionam a excessiva 
preocupação do indivíduo consigo mesmo, com seu autodesenvolvimento e ao o fato de que as velhas ordens comunais foram rompidas, Lash (1983) associa a sociedade atual a uma característica narcísica, assim denominada por ele, sem a preocupação com o passado e o futuro. Para esses autores, os processos de modernização e individualização encontram-se imbricados, conduzindo a uma ruptura do sentido histórico nas sociedades modernas. Perde-se o sentimento de pertencimento a uma comunidade ou de continuidade geracional, por exemplo. Também se perdem os vínculos com as instituições tradicionais e os valores modernos. Para estes, perdeu-se o sentido da comunidade histórica e o sentimento de pertencer a uma geração enraizada no passado, porque o sentido histórico foi perdido com as metanarrativas, os valores tradicionais e as instituições tradicionais modernas. Os indivíduos já não mais se vinculam a instituições, mas, ao contrário, nelas e em seus valores eles não mais acreditam. Essa é uma das sequelas do declínio dos sujeitos coletivos e de suas instituições, como o Estado-Nação, a dimensão comunitária e os sindicatos, que garantiam a proteção dos indivíduos e de seus direitos. Isso não significa que não haja mais a existência de categorias como família, classe, gênero, religião, comunidades e sindicatos, mas, sim, que elas foram transformadas e, muitas vezes, relegadas a segundo plano. Não serão mais elas a guiar as biografias individuais.

Nesse sentido, Beck $(2011)^{1}$ afirma que as mudanças sociais no interior da sociedade contemporânea

\footnotetext{
1 Para Beck (2011), na Alemanha do pós-guerra, desenvolveu-se uma dinâmica socioestrutural que não pode ser explicada por meio da teoria de classe de Marx e Engels (classe definida pelo seu lugar em determinado sistema histórico de produção social e sua relação com os meios de produção). Dessa forma, o autor questiona a análise social a partir da leitura dos grandes grupos tradicionais, como classe e estamentos.
} 
(sociedade de risco - termo utilizado pelo autor) desprendem o indivíduo das formas sociais tradicionais da sociedade industrial (primeira modernidade), e, consequentemente, das categorias tradicionais (classe e estamento, por exemplo) que formavam as bases do modo de pensar a sociedade. As transformações entre indivíduos e sociedade foram tão profundas, segundo ele, que as distinções de classes sociais não determinam mais, exclusivamente, a formação das identidades. Tais mudanças não significam que desapareçam as desigualdades fundamentadas nas clivagens da primeira modernidade. 0 que ocorre é uma ressignificação com base no processo de individualização, ou seja, os problemas sociais passam a ser compreendidos também segundo a individualidade de cada um e não unicamente na sua conformação coletiva.

De acordo com Beck (1997, p. 18-19), isso conduz à imposição de todo esforço e culpabilidade sobre o próprio indivíduo:

As oportunidades, ameaças, ambivalências da biografia que, anteriormente, era possível superar em grupo familiar, na comunidade da aldeia ou se recorrendo a uma classe ou grupo social, devem ser cada vez mais percebidas, interpretadas e resolvidas pelos próprios indivíduos. Certamente ainda podem ser encontradas nas famílias, mas as famílias nucleares estão se tornando uma instituição cada vez mais rara. Há desigualdades crescentes, mas as desigualdades e a consciência de classe perderam sua posição central na sociedade.

Para o autor, a individualização não implica substituir as antigas certezas por uma situação de vazio. Ao contrário, o processo de individualização produz uma 
compulsão pela procura de novas certezas. Trata-se do surgimento de uma nova forma de conduzir a vida, já não mais presa às tradições.

Posto isso, é importante ressaltar que a individualização caminha concomitante às tendências de novas formas de institucionalização e padronização de condições de vida. Os indivíduos livres tornam-se dependentes do mercado de trabalho e, consequentemente, dependentes de qualificação e formação para conseguirem inserir-se nesse mercado, bem como dependentes da oferta e dos meios para o consumo, das regras sociojurídicas que lhes concedem direitos, da ciência, da medicina, da psicologia etc. Em suma, o processo de libertação da institucionalidade tradicional moderna aponta para outras e novas contradições, pois liberta e também produz novas dependências, que são, por sua vez, institucionalizadas e padronizadas.

Tal como Beck (1997), que analisa as transformações da sociedade contemporânea, Lipovetsky (2004) acredita que, a partir do último quarto do século $\mathrm{XX}$, a modernidade ingressou em uma fase de radicalização da modernidade, denominada por ele como hipermodernidade. $\mathrm{O}$ atual momento, hipermoderno, instantâneo e fluido, tem como característica a cultura do narcisismo, representado por uma monumental explosão do neoindividualismo.

[...] o individualismo sofre uma atualização que aqui chamamos de narcisista, de acordo com a definição dos sociólogos norte-americanos: narcisismo, consequência e manifestação miniaturizada do processo de personalização, símbolo da passagem do individualismo limitado ao individualismo total, símbolo da segunda revolução individualista (LIPOVETSKY, 2005a, p. 21). 
Para o autor, os atuais ordenamentos e instituições sociais servirão, tão somente, como objetos de escolha para os indivíduos construírem suas próprias identidades. De fato, as instituições e os organismos reguladores que, na primeira modernidade, estruturavam a escolha dos indivíduos por meio dos serviços oferecidos, agora, nesse período que o autor chama de neoindividualismo, esses serviços são utilizados de acordo com os interesses individuais e não mais em sua dimensão social ou coletiva. No livro A era do vazio, Lipovetsky (2005a) apresenta a desagregação da sociedade moderna e dos costumes, o enfoque do indivíduo contemporâneo no consumo de massa e a emergência de um modelo de individualização em ruptura com os paradigmas tradicionais dos séculos XVII e XVIII. Esse momento histórico marca um período de ruptura com todas as instituições que se opunham à liberdade e à autonomia dos indivíduos. É o momento em que freios se rompem, permitindo a emergência e a manifestação dos desejos subjetivos e sua realização individual.

A cultura pós-moderna é um vetor do aumento do individualismo; diversificando as possibilidades de escolha, liquidificando os pontos de referências, minando o sentido único e os valores superiores da modernidade, ela administra uma cultura personalizada sob medida, que permite ao átomo social emancipar-se do balizamento disciplinar revolucionário. (LIPOVETSKY, 2005a, p. 21).

Assim como Bauman (2001), Lipovetsky (2004), afirma que esse novo paradigma individualista é consentâneo a vários fatores, tais como as inovações dos meios de comunicação e do transporte, e do desenvolvimento 
das transações comerciais, inerentes ao estado atual do capitalismo, que se assume como consumista. É assim que, ancorada no individualismo, formou-se uma sociedade hedonista que envolve, quase indistintamente, todos os segmentos e classes sociais. Lipovetsky (2004) refere-se ao atual momento como a "[...] sedutora leveza do ser" e Bauman (2001) como o "[...] tempo instantâneo", no sentido de ausência e volatilidade de interesses. Se o início da modernidade foi o tempo dos engajamentos mútuos, a sociedade contemporânea pode ser considerada a da era do enfraquecimento dos engajamentos coletivos. Em prol das condutas livremente escolhidas e assumidas pelos indivíduos, erodem-se as grandes narrativas, os discursos tradicionais. As ideologias políticas coletivas já não inflam multidões. Com uma visão talvez um pouco pessimista, Lipovetsky (2004) afirma que, em vez da disciplina, do laicismo e da vanguarda, prevalecem, atualmente, o indivíduo, o consumo e o hedonismo.

Em uma sociedade capitalista e pós-industrial, essa nova forma de autoconstrução - da individualização personalista -, com tamanha gama de ofertas a escolher para assim compor a existência individual, leva à radicalização de outro fenômeno: o consumo, que se tornou o principal vetor social de construção da individualidade (BAUMAN, 2001; LIPOVETSKY, 2004).

Se o consumo é o meio de construção do self, a identidade torna-se passageira, pois os produtos são temporais. No contexto do processo capitalista, os produtos alteram-se com as propagandas e, com eles, surge a necessidade de novos consumos e, consequentemente, a construção de novas identidades. A posse de determinados objetos de consumo passa a ser condição de conformação de 
identidade, a ser assumida ou não. Sem a obrigatoriedade da conduta condizente com a comunidade, o indivíduo torna-se livre da tradição, mas agora ele se encontra preso às amarras da lógica capitalista contemporânea. Sua liberdade é novamente limitada, pois suas opções de construção de identidades individuais dependem de recursos para o acesso ao consumo. É nesse sentido que os recursos facilitam ou dificultam a sobrevivência no mundo contemporâneo (BAUMAN, 2001).

Numa sociedade de consumo, compartilhar a dependência de consumidor - a dependência universal das compras - é a condição 'sine qua non' de toda liberdade; acima da liberdade de ser diferente, de ter identidade. (BAUMAN, 1998, p. 89).

Segundo a teoria de Bauman (1998), a centralidade do consumo opera objetivação e instrumentalização das relações sociais, ou seja, o processo de consumo afeta todas as relações, que passam a ser reduzidas às relações de consumo. Amizade, namoro, casamento, família são afetados pela lógica do consumo como o ideal do agir na sociedade contemporânea. Tornam-se também objetos de consumo - são úteis enquanto satisfazem e dispensáveis quando não mais possuem utilidade. As relações sociais na sociedade contemporânea constroem-se pela lógica do consumo, tornam-se voláteis e fluidas, e fragilizam as redes que sustentavam a coesão social estabelecida nos moldes da primeira modernidade.

O mundo construído de objetos duráveis foi substituído pelo de produtos disponíveis projetados para imediata obsolescência. Num mundo como esse, as identidades podem ser adotadas e 
descartadas como uma troca de roupa. 0 horror da nova situação é que todo diligente trabalho de construção pode mostrar-se inútil; e o fascínio da nova situação, por outro lado, se acha no fato de não estar comprometida por experiências passadas, de nunca ser irrevogavelmente anulada, sempre 'mantendo as opções abertas'. (BAUMAN, 1998, p. 112-113).

Em seu livro Modernidade líquida, Bauman (2001) afirmou que a sociedade saiu de um capitalismo pesado para um sistema capitalista fluido e leve. Tal capitalismo ativa, precisamente, o motor do consumo. No atual estágio do capitalismo, a relação mercadoria-consumo vem sendo transformada, pois, ao contrário do capitalismo pesado, em que a consigna era a acumulação de bens, na sociedade atual tem-se como mote a substituição do objeto consumido em uma temporalidade muito rápida. Esse fato é induzido pela intensidade das inovações tecnológicas. Diz o mesmo autor que, enquanto no capitalismo pesado o modo de produzir esteve fortemente ancorado na concepção fordista de racionalidade hierárquica e tecnocrática, a atual configuração da sociedade está ligada às velocidades das mudanças situacionais, que aportam flexibilização e conduzem a variadas formas de produção. De fato, a inovação é intrínseca a esse modo de produção e consumo, que é, também, incentivado por um marketing massivo e sedutor. Toda essa nova dinâmica atinge em cheio as relações de trabalho, tornando-as permanentemente instáveis.

Não obstante, independente da modalidade do capitalismo, ambas as suas formas aprisionam o consumidor pelo desejo e geram o vazio na impossibilidade de preencher e saciar sua vontade. Em suma, o excesso e a falta tangenciam o capitalismo leve e pesado (BAUMAN, 2001). 
Como se observa, para Bauman (2001), o consumo torna-se, no atual momento, a base principal pela qual o indivíduo constrói sua identidade. É por meio da incorporação simbólica absorvida com o consumo que se criam diferentes formas de identidade e sentimentos. Tem-se hoje, portanto, um vínculo entre a busca da felicidade e o consumo de mercadorias. Dessa forma, a busca frenética pela felicidade imposta pelas campanhas publicitárias impulsiona o descarte dos objetos, assim que novos são lançados. 0 consumo transforma a identidade e a felicidade em objetos a serem adquiridos.

A angústia da liberdade de escolha cria no consumidor a sensação de estar sempre a reinventar-se e a tecer sua própria história. No plano do inconsciente social, um objeto é ostentado como forma de integrar o indivíduo, que busca sair do anonimato e da impessoalidade para aderir à esfera da aceitação de um grupo no qual deseja inserir-se, ou seja, a busca do reconhecimento do outro (LIPOVETSKY, 2005a).

A dissolução do sujeito pelas regras da lógica do consumo cria uma nova identidade do indivíduo, que se identifica com mercado, como o modelo de individualização e personalização. No entanto, e contraditoriamente, os limites desse modelo são logo percebidos pelo indivíduo, pois os sentimentos construídos pelo consumo desses produtos fluidos destroem a autonomia desse mesmo indivíduo. A propósito, ao referirmos o consumo, não estamos a falar aqui somente das chamadas mercadorias-objeto, mas também de atividades de trabalho, de lazer etc.

Estamos destinados a consumir cada vez mais objetos, informação, esportes, viagens, formação, 
relações, músicas e cuidados médicos. Isto é a sociedade pós-moderna: não além do consumismo, mas sim, na sua apoteose, na sua extensão até a esfera particular [...]" (LIPOVETSKY, 2005a, p. 19).

Para Lipovetsky (2005a), o atual processo de individualização, a que ele denominou de narcisista, carrega uma nova característica intrínseca, que é a personalização. Nesse sentido, tudo é feito sob medida para o indivíduo: combinações de roupas, métodos de ensino, de atendimento, de tratamento médico, terapia psicanalítica etc. Tudo é personalizado e oferece a ideia de ser feito sob medida.

Na ordem psicoterapêutica, surgem novas técnicas que "[...] dão mais audácia ainda à personalização psicanalítica" (LYPOVETSKY, 2005a, p. 5), como as análises transacionais, grito primal e bioenergia, que permitem a liberação direta do sentimento, das emoções, da energia corporal. É a exploração mental/psíquica do corpo em ruptura com o diagnóstico puramente clínico. 0 corpo é bio-psíquico-social. "0 doente não deve mais aceitar seu estado passivamente, pois é o responsável pela sua saúde e pelos seus sistemas de defesa graças aos potenciais da autonomia psíquica" (LYPOVETSKY, 2005a, p. 5).

Em paralelo, os esportes e as atividades ao ar livre vêm ganhando cada vez mais espaço, sobretudo os esportes individuais e sob encomenda, que podem ajudar a psicologizar o corpo e desenvolver uma consciência sobre si mesmo: yoga, pilates, alongamento, corridas, ginástica laboral, natação, caminhada e bicicleta.

A cultura pós-moderna é a cultura do feeling e da emancipação individual estendida a todas as 
categorias de idade e de sexo. A educação, antes autoritária, tornou-se altamente permissiva, atenta aos desejos das crianças e dos adolescentes enquanto, por toda a parte, a onda hedonista elimina a culpa do tempo livre e encoraja a nossa entrega a ele sem entrave e o aumento da quantidade de lazer (LYPOVETSKY, 2005a, p. 5).

Segundo Lipovetsky (2005a), a sociedade atual passa a privilegiar a diversidade no oferecimento de serviços diferenciados nas diversas áreas da vida social, das relações sociais e das estruturas familiares, como na moda, no turismo, nos estudos, nos tratamentos de saúde e em outros mais. Nesse sentido, não se fala mais de homogeneização, mas na personalização das ofertas, tendo como objeto o indivíduo.

Da mesma forma que os indivíduos são plurais e distintos, tudo tem de parecer individualizado e distinto. 0 processo sistemático de personificação tem por finalidade "[...] multiplicar e diversificar a oferta, em oferecer mais para que você possa escolher melhor, em substituir a indução uniforme pela livre escolha, a homogeneidade pela pluralidade, a austeridade pela satisfação dos desejos" (LYPOVETSKY, 2005a, p. 3). Sua identidade não está mais definida pelo país de origem, pela concordância entre o sexo e sua designação social de gênero, pela família, idade, classe social e trabalho. Ela pode ser plural e modificar-se a todo o momento, segundo as escolhas feitas individualmente. Não é mais fixa nem deve acompanhar o indivíduo por toda sua vida. "[...] surgem por assim dizer módulos pré-fabricados de possibilidades combinatórias de natureza biográfica. Na transição da biografia padrão para a 22 biografia eletiva" (BECK, 2011, p. 199). 
Em suma, o individualismo da sociedade contemporânea diferencia-se do instituído pela sociedade moderna por não estar mais submisso às imposições e ordenamentos dos organismos ou instituições sociais. A valorização da noção de igualdade cedeu lugar à diferenciação, à liberdade de construção da identidade e à sobreposição do individual sobre o coletivo. Paradoxalmente, porém, a sociedade contemporânea tem criado novas formas de engessamento e padronização do indivíduo baseado no consumo. Tais transformações impactam as relações entre a sociedade e o Estado, bem como as instituições políticas modernas, impactos esses que serão objeto da explanação a seguir.

\section{TRANSFORMACŌEES SOCIOPOLITICAS}

Posto o panorama de individualização e consumo, cabe agora analisar a crise da institucionalidade do Estado em decorrência dos impactos das transformações da própria sociedade contemporânea. Parte-se do pressuposto de que há uma tripla crise: 1) crise da soberania do Estado-Nação, em virtude da globalização; 2) crise da governabilidade, em consequência das dificuldades do Estado na resposta às demandas sociais; 3) crise institucional do Estado, como resultado da falta de identificação da sociedade com as instituições governamentais e a própria política representativa.

A análise que segue está dividida em duas partes: a crise do Estado-Nação; e as transformações na relação entre a sociedade e as instituições políticas, abarcando a segunda e a terceira crises do Estado-Nação. 
Antes de ingressar nos motivos e nas consequências das crises e transformações do Estado na sociedade contemporânea, é necessário resgatar como a política e a institucionalidade do Estado manifestaram-se no período que denominamos de primeira modernidade (que vai do início da Revolução Industrial até o declínio da ordem social socialista).

A ideia de política moderna tem como característica primordial o seu desenvolvimento em um espaço delimitado territorialmente, vale dizer, nos limites do próprio Estado-Nação.

A história da formação do Estado-Nação percorreu um longo período do processo histórico, carregado, muitas vezes, de violência. Passou pelo estabelecimento e consolidação de uma autoridade central (o rei), em que os feudos a ela submeteram-se, com a participação, embora algumas vezes contraditória, de uma organização supranacional, a da igreja. 0 resultado desse arranjo institucional, decorrente da imposição da autoridade central do monarca, vincula-se, intimamente, à própria constituição do capitalismo. 0 poder central definiu o seu território (a Nação), que, por sua vez, deu identidade política aos habitantes desse território (DALLARI, 2001).

Segundo Dallari (2001), os conceitos inerentes ao Estado-Nação são: o território, o povo e a soberania. Território é a extensão necessária para o Estado localizar-se no espaço terrestre, marítimo e aéreo. Povo é o conjunto de indivíduos que integra o Estado por meio da vinculação jurídica e, assim, adquire a condição de cidadãos. É da intersecção dos conceitos de povo e território que surge a ideia de nação. Nação é a comunidade de base histórico-político-cultural que integra todos os indivíduos que 
nascem em certo ambiente cultural, com tradições e línguas comuns. Por fim, soberania está relacionada com a ideia de autoridade suprema. É o direito exclusivo de uma autoridade sobre um grupo de indivíduos. A soberania se manifesta, principalmente, pela constituição de um sistema de normas jurídicas (DALLARI, 2001; BOBBIO, 1999).

[...] tendo em conta a possibilidade e a conveniência de se acentuar o componente jurídico do Estado, sem perder de vista a presença necessária dos fatores não-jurídicos, parece-nos que se poderá conceituar o Estado como a ordem jurídica soberana que tem por fim o bem comum de um povo situado em determinado território. Nesse conceito se acham presentes todos os elementos que compõem o Estado, e só esses elementos. A noção de poder está implícita na de soberania, que, no entanto, é referida como característica da própria ordem jurídica. A politicidade do Estado é afirmada na referência expressa ao bem comum, com a vinculação deste a um certo povo e, finalmente, territorialidade, limitadora da ação jurídica e política do Estado, está presente na menção a determinado território. (DALLARI, 2001, p. 45).

A respeito da relação Estado, direito, soberania e poder, Dallari (2001) afirma que o Estado deve procurar o máximo de juridicidade e que em seu caráter de ordem jurídica estão sintetizados os elementos componentes do Estado. Contudo, ele explica que isso não é nada fácil, pois,

[...] enquanto sociedade política, voltada para fins políticos, o Estado participa da natureza política, que convive com a jurídica, influenciando-a e sendo por ela influenciada, devendo, portanto, exercer um poder político. Este é o aspecto mais difícil 
e mais fascinante do estudo do Estado, pois introduz o estudioso numa problemática extremamente rica, dinâmica e polêmica, onde se faz presente a busca dos valores fundamentais do indivíduo, da sociedade e do Estado, a par da procura da organização mais eficaz para a promoção desses valores. (DALLARI, 2001, p. 48).

0 autor aponta, ainda, um quarto elemento relativo à concepção do Estado, qual seja, suas funções e finalidades. Tal concepção diz respeito ao conteúdo relativo a toda atividade estatal, que determina a estrutura fundamental do Estado (burocracia e máquina pública) que, em síntese, organiza suas atividades por meio de regras racionais, gerais e abstratas, travestidas na lei emanada do próprio Estado.

Os processos mais significativos na constituição do Estado-Nação foram: fronteiras territoriais, sistema uniforme de leis, mecanismos de elaboração e imposição das leis, centralização do poder administrativo, estabelecimento de impostos e gestão fiscal, criação de uma força armada nacional - exército e constituição de uma diplomacia para regular as relações entre os Estados. É formado por um aparato de instituições que exercem os poderes político, administrativo e normativo. A conformidade da sociedade moderna exigiu, assim, um poder centralizado que concentrasse os instrumentos capazes de administrar os desafios e as exigências de uma economia capitalista. 0 Estado, por assim dizer, é uma manifestação moderna decorrente do processo de racionalização (WEBER,1998; BOBBIO, 1987).

Podemos vislumbrar essas características a partir de teorias da soberania estatal em pensadores contratualistas, como Hobbes (1999), Locke (2006) e Rousseau (1999). Hobbes (1999) foi um dos primeiros teóricos a 
tratar da noção central de soberania de um Estado e das condições para o exercício legítimo sobre um território e uma população. Posteriormente, a ideia de soberania do Estado transformou-se em soberania popular com Locke (2006) e Rousseau (1999), dos quais emerge a noção de que a fonte e a origem do poder político devem ser consentidas pelos cidadãos. E assim, gradativamente, expande-se a noção da democracia moderna, em que a origem da soberania do poder Estatal dá-se pela vontade geral.

Apesar da relevância de tais autores para o pensamento moderno, aqui nos deteremos em dois outros estudiosos que permearam as teorias sociológicas e políticas no século XX e que foram, de alguma forma, influenciados pelos anteriores, são eles: Max Weber e Antônio Gramsci.

Weber (1998) identifica como característica do Estado moderno a dominação racional, baseada na crença da legalidade das ordenações, fundada em regras racionalmente criadas - as leis. O Estado moderno seria, portanto, uma instituição racional que agiria por meio de uma administração estabelecida constituída de uma burocracia e de uma concepção jurídica, nas quais essa administração deve ser pautada. Segundo esse raciocínio, o Estado moderno abrange atributos da força física, da noção de território e da burocracia.

No que concerne ao exercício do monopólio da coação física legitimada, o Estado moderno é "[...] uma relação de domínio de homens sobre homens, baseada no instrumento de força legítima (quer dizer, considerada legítima). 0 Estado só pode existir, portanto, sob a condição de que os dominados submetam-se à autoridade continuamente reivindicada pelos que dominam" (WEBER, 1996, p. 56 apud NOGUEIRA, 2013, p. 337). 
Com relação ao território, é ele que estabelece os limites do exercício da coação física. A atividade política é definida pelo fato de desenrolar-se no território delimitado. É, portanto, necessário que as fronteiras sejam fixadas e que se delimite um agrupamento, criando-se uma separação entre o interior e o exterior. Os que estão no interior, os cidadãos, adotam um comportamento orientado segundo o território e a comunidade correspondente, e têm suas atividades e os limites de sua liberdade condicionados pela autoridade encarregada da ordem, o Estado (WEBER, 1998).

Constitui ainda característica do Estado moderno a burocracia, os funcionários do Estado que pautam suas atividades segundo regras racionais, gerais e abstratas: a lei emanada do próprio Estado, sendo, portanto, uma atividade impessoal e vinculada. Isso quer dizer que a necessidade de racionalização faria com que o Estado se legitimasse e crescesse com uma burocracia capaz de incrementar o poder político mediante rotinas técnicas, administrativas e legais. A burocracia seria a própria capacidade de organização da máquina administrativa do Estado moderno (WEBER, 1998).

Já Gramsci (1968), por sua vez, foi um pensador que rompeu com a tradição jusnaturalista ao pressupor a existência de formas de associação que antecedem o Estado e que correspondem à sociedade civil. Ele não abandona a dicotomia estrutura/superestrutura pela sociedade civil/Estado, mas também não desenvolve sua teoria com base no determinismo econômico de Marx, envolvido na primeira dicotomia. De acordo com Carnoy (1988), a distinção entre Gramsci e Marx é que, na concepção marxista, a sociedade civil é estrutura, ou seja, ela representa as 
relações de produção. Na concepção gramsciana, ela é a superestrutura, isto é, corresponde às relações de produção. No que concerne à concepção gramsciana, ela corresponde aos fatores ativo e positivo no desenvolvimento histórico, ou seja, é a superestrutura. Nesse sentido, para Gramsci (1968), a sociedade civil é o complexo das relações ideológicas, culturais e intelectual.

Segundo Gramsci (1968), a superestrutura conta com dois níveis, a sociedade política e a civil, sendo a primeira o conjunto de mecanismos por meio dos quais a classe dominante dispõe o monopólio da violência (burocracias e Forças Armadas), e a segunda, o conjunto de organizações públicas e privadas responsáveis por elaborar e difundir as ideologias. É nesse sentido que esse pensador amplia o conceito de Estado, ao afirmar que "[...] na noção geral de Estado entram elementos que também são comuns à noção de sociedade civil (neste sentido, poder-se-ia dizer que Estado = sociedade política + sociedade civil, isto é, hegemonia revestida de coerção)" (GRAMSCI, 1968, p. 149).

0 Estado é assim definido como "[...] todo o conjunto de atividades teóricas e práticas com as quais a classe dirigente justifica e mantém não somente a sua dominação, mas também consegue obter o consenso ativo dos governados" (GRAMSCI, 1976, p. 87).

Posto esse rápido panorama da construção teórica do Estado Moderno, cabe agora analisar as transformações pelas quais ele vem passando na sociedade contemporânea.

Como já citado na primeira parte deste capítulo, a política, na primeira modernidade, estava centrada no Estado, ou seja, dentro dos limites do Estado-Nação é que ela 
se manifestava. Essa é uma das características que mais sofreu alteração com as transformações da sociedade contemporânea, visto que essa ideia de fronteira trazia consigo o processo conhecido por desterritorialização.

A manifestação mais eloquente da desterritorialização é o fenômeno da globalização, que Giddens (1991, p. 69) define como sendo "[...] a intensificação das relações sociais em escala mundial, que ligam localidades distantes de tal maneira que os acontecimentos locais são modelados por eventos ocorrendo a muitas milhas de distância e vice-versa”.

Com o fenômeno da globalização na segunda metade do século XX, o Estado-Nação passou a sofrer a competição de instituições supranacionais de poder. Na globalização, segundo Giddens (1997), os laços estendem-se muito além das fronteiras tradicionais das comunidades e das nações, levando em si um novo sentido de organização social e política. Dessa forma, as relações sociais ultrapassam os contextos locais de interação e são reorganizadas em outra magnitude de tempo e espaço. A história, a cultura, as relações, as vivências individuais e coletivas são modificadas cotidianamente. Tudo é transformado pela velocidade eletrônica, imprimindo novos ritmos à sociedade em rede (CASTELLS, 1999a).

A vida das nações, empresas, instituições e partidos torna-se, de modo geral, organizada segundo padrões universais de eficácia, lucro e produtividade. Essa razão instrumental começa a ordenar tempo e espaço, o modo de consumo, de pensar e agir. Consequentemente, as identidades culturais pré-modernas acabam enfraquecendo. Simulacros, virtualidades e imagens passam a desempenhar papel importante na vida social, à medida que aceleram a 
racionalização das organizações e as atividades baseadas na técnica, na eletrônica e na informática (IANNI, 2003).

Dessa forma, assistimos ao enfraquecimento das fronteiras, ao surgimento de capital volátil e até mesmo ao afrouxamento do poder soberano do Estado-Nação, que, assim, tem vivido uma crise de legitimidade tanto de suas instituições como de seus representantes, pois, confrontado com fluxos globais de capitais, de produção, de comércio, de informação e de gestão, foi perdendo parte de seu poder. 0 Estado tem passado pelo desafio de aprender a navegar em fluxos globais, bem como a ressignificar seu poder de soberano em termos de governo ante a sociedade, modelo que esteve na base de sua formação.

[...] os quadros mentais de referência, fortemente enraizados na hipótese da sociedade nacional, do Estado-Nação, adquirem outras possibilidades de expressão. Rompem-se os significados dos conceitos, categorias, leis e interpretações codificados nas noções de sociedade civil, Estado Nacional, povo, cidadão, classe social, grupos étnicos, movimento social, partido político, corrente de opinião pública, diversidade, desigualdades, antagonismos. (IANNI, 1997, p. 105).

A luta política na modernidade tinha como palco e objetivo a conquista e a manutenção do poder estatal, visando o bem comum e um interesse geral da nação. Já na sociedade contemporânea, com a intensificação do processo de individualização, o jogo político ocorre na arena da sociedade civil. Aqui se tem, como proposta, a conquista de finalidades grupais ou segmentares, pois seus fins visam a interesses micros e individuais.

Segundo Rouanet (1992, p. 237), 
[...] assim como não há mais atores políticos universais - grandes partidos agregando um leque amplo de interesses e posições -, não há mais um 'poder' central localizado no Estado, mas um poder difuso, estendendo sua rede capilar por toda a sociedade civil - as 'disciplinas' de Foucault. Políticas segmentares, exercidas por grupos particulares, política micrológica, destinada a combater o poder instalado nos interstícios mais imperceptíveis da vida cotidiana, estamos longe da política moderna, em que o jogo político se dava através de partidos, segundo os mecanismos da democracia representativa.

Os cidadãos, como sujeitos coletivos, pulverizaram-se em suas características individuais, restringindo-se às suas particularidades de mulher, negro, judeu, homossexual etc. Consequentemente, a política universalista/genérica passa a não ser mais efetiva ou mesmo legitimada por seus públicos-alvo. 0 cidadão exige, assim, políticas específicas, inscritas nos campos setoriais da diversidade existente na sociedade.

Pode-se aferir que, em meio a essas grandes transformações, a política institucional e o campo das administrações públicas também sofrem impactos. Apesar de elas ainda estarem ancoradas na lógica do território nacional e da soberania, constituídas na modernidade, é nítido que se torna cada vez mais árduo ao Estado responder à sociedade com base nessa lógica, o que demonstra um descompasso das instituições públicas com as transformações sociais. "El mercado y el poder económico subyacente se han globalizado, mientras las instituiciones politicas, y el poder que de ellas emana, siguen en buena parte anclados 32 al território" (SUBIRATS, 2012, p. 2). 
Se o projeto moderno aspirava a uma sociedade planejada e administrada de forma científica para a definição de uma política pública, é porque se acreditava que o conhecimento produzido pela ciência seria garantia de sucesso. Hoje, sabe-se que esse projeto moderno não atingiu seu objetivo e têm-se a certeza de que a ciência não é um saber positivo e neutro. Sabe-se também que para elaborar uma política pública, como um programa de saúde, os atores responsáveis por sua elaboração e execução devem contemplar um conjunto de aspectos alheios à ciência, mas que interferem no alcance de suas metas. São aspectos ideológicos, políticos, culturais, institucionais e éticos. Ademais, devem-se contemplar todos os atores envolvidos na política e o próprio público-alvo. 0 Estado já não pode mais elaborar e executar sozinho a política pública, nem elaborá-la de forma homogênea, sem considerar as distinções existentes na sociedade.

Para Subirats (2012), a lógica hierárquica formal não serve mais para fundamentar o processo de decisão pública, que cada vez mais encontra-se baseado na lógica da interdependência e relacional.

Se ha ido poniendo de relieve que el Estado no es ya la representación democrática única e indiscutida de un conjunto de indivíduos, sino un simples actor a más en el escenario social. Un actor a más, y muchas veces, no el más fuerte, en la dinámica del mercado global. Un actor que resulta cada vez más condicionado y limitado en su capacidad de accíon por la creciente colusión de sus políticas con los intereses privados. (ibidem, p. 3).

Argumenta-se, pois, que a sociedade industrial moderna vem-se desestabilizando em sua própria estrutura, 
tornando-se cada vez mais complexa e abrangendo as tendências particulares do mundo pós-industrial, quais sejam: a desvalorização da política e a crise do Estado como instância de coordenação e planejamento; a fragmentação e a diversificação dos interesses; e o crescimento do individualismo (NOGUEIRA, 2001).

Em relação à política, essa crise implica o esvaziamento das instituições democráticas e o comportamento autoritário e tecnocrata dos poderes executivos. É visível hoje a inabilidade dos partidos políticos e do próprio Estado em lidar com a dinâmica social, com situações complexas e diferenciadas que se modificam rapidamente e exigem não só maior rapidez nas respostas, como também a participação mais efetiva dos atores sociais, sem ser pelas vias institucionais existentes (por exemplo, os conselhos, que se tornam instâncias cooptadas pela burocracia administrativa).

Basicamente, podemos citar dois fenômenos que dificultam a resposta do Estado às demandas sociais, bem como a falta de identificação da sociedade com as instituições governamentais e a própria política representativa: o pluralismo social, que traz em sua essência o direito de ser diferente (consequência do fenômeno do individualismo), e a emergência de um novo tempo/espaço tecnológico.

Com relação ao primeiro, o pluralismo basicamente afeta a política em dois quesitos: a necessidade por políticas específicas e não mais homogêneas, e a demanda por mais direitos e reconhecimentos individuais. Como pontua Carvalho (2009), nessa tendência ideológica e nesse momento histórico, o direito ao consumo desponta como o pilar da sociedade contemporânea. 0 novo cidadão desponta como consumidor de direitos, de reconhecimento, de mercadorias, de cultura, de identidades, de saúde. 
Dessa maneira, podemos aproximar o discurso de Carvalho (2009) ao de Bauman (1999a) e Lipovetsky (2005a; 2005b) à multiplicidade dos direitos individuais. A sociedade contemporânea é caracterizada pela tendência a aumentar a oportunidade das escolhas individuais de tal maneira que os cidadãos pulverizam-se em suas características individuais e demandam, cada vez, mais direitos específicos relacionados à sua individualidade.

Dessa forma, na sociedade contemporânea, devido ao pluralismo social existente, há uma imensa luta por novos direitos e novos reconhecimentos identitários. Há o aumento e a diversificação de demandas individuais e minoritárias - exigências que se tornam cada vez mais difíceis de serem atendidas. 0 Estado-Nação, que desde seu nascimento esteve voltado a administrar o coletivo e a produzir políticas homogêneas, vê-se na encruzilhada de conseguir administrar direitos e demandas individuais.

As mudanças ocorridas no padrão da demanda são um indício forte de que a dinâmica dos processos políticos tornou-se mais rica e complexa. São demandas pelo direito ao casamento homoafetivo, por tratamentos de saúde específicos, pela reprodução assistida, pela escolha de determinado serviço de saúde ou terapêutica - um hospital, certo tratamento medicamentoso, por exemplo -, pelo transporte, pela educação, por terapia, por praticar esporte etc. São demandas individualizadas ou de grupos específicos. Não são mais estritamente de uma classe.

Os interesses, as exigências e as reivindicações fragmentaram-se, sobrecarregando os processos e procedimentos da representação e da decisão política. 0 jogo político é hoje segmentar, exercido sob formas particulares e muito distinto do da política moderna, em que os jogos 
políticos davam-se por meio dos partidos e segundo os mecanismos da democracia representativa.

Os partidos políticos não representam mais as inúmeras identidades sociais, pois estas, na sociedade contemporânea, são individuais, são micrológicas. Não são mais as classes, mas sim os elementos que constituem suas particularidades: a de ser mulher, negro, homossexual, judeu e outras. A sociedade civil fragmentou-se em grupos identitários e, portanto, suas demandas são individualizadas.

0 movimento de individualização que se alastra no Ocidente desde a segunda metade do século XX é um elemento paradoxal, emergido dentro da própria sociedade capitalista industrial e que vem gestando uma nova forma de sociabilidade e apresentando um desafio para as próprias instituições políticas que não conseguem compreendê-lo.

A cultura pós-moderna representa o pólo 'supernatural' de uma sociedade que está saindo de um tipo de organização uniforme, administrativa e que, ao fazê-lo, enfraquece os últimos valores modernos, reergue o passado e a tradição, torna a valorizar o lugar e a vida simples, dilui a preeminência da centralização, dissemina os critérios do verdadeiro e da arte, legitima a afirmação da identidade pessoal de acordo com os valores de uma sociedade personalizada na qual o importante é ser a própria pessoa e onde, por conseguinte, qualquer coisa tem direito de cidadania e de reconhecimento social, onde nada mais deve ser exigido imperiosa e duravelmente, onde todas as opções, todos os níveis podem conviver sem contradição nem relegação (LYPOVETSKY, 2005a, p. 20).

0 questionamento da tradição, o hiperindividualismo e a instabilidade das normas de socialização colocam 
em risco a coesão social contemporânea e o desengajamento político? Não. É curioso notar que o individualismo não elimina a participação coletiva, somente altera a forma pela qual ela ocorre. 0 engajamento coletivo contemporâneo dá-se pela lógica da individualização.

Muitas vezes, os interesses individuais prevalecem sobre os sociais, a autonomia individual sobre a ortodoxia doutrinal, a participação livre sobre a coletividade, a ação direta sobre a representatividade. 0 esvaziamento dos grandes movimentos sociais e o enfraquecimento da credibilidade dos partidos políticos como instituições detentoras de grandes perspectivas históricas são sintomas das características dos novos paradigmas contemporâneos.

Lipovetsky (2005a) considera que o advento da sociedade hiperindividualista não põe fim às lutas sociais, pois, em meio ao individualismo, surgem variadas formas de engajamento em ações coletivas com as quais os indivíduos podem envolver-se livremente, sem se submeterem a qualquer instância superior. A existência de autonomia privada reencontra-se nas ações coletivas, independentemente das organizações políticas e sindicais. Mobilizações, muitas vezes e aparentemente despolitizadas, desideologizadas e dessindicalizadas, aparecem por toda parte, sustentadas pelas reivindicações individualistas de melhoria das condições de trabalho, transporte, moradia, poder de consumo etc.

Para Lipovetsky (2004), o predomínio do ego avança sobre o terreno das ações coletivas em proveito dos próprios indivíduos. Tais avanços ocorrem nas mais diversas dimensões (política, econômica, cultural etc.), afastando-as das utopias modernas e aproximando-as dos interesses 
particulares. "[...] embora o sacerdócio do dever e os tabus vitorianos tenham caducado, nascem novas regulações, reconstituem-se proibições, restauram-se valores" (LIPOVETSKY, 2004, p. 38). A sociedade civil imprime uma nova ordem, ainda difícil de compreender, se a olharmos com base nos paradigmas modernos, ou sólidos, como denomina Bauman (2001).

Na análise de Lipovestky (2005b), em A sociedade pós-moralista, é preciso entender o que está no centro das motivações individuais quanto a ações e ajustamentos específicos em prol de soluções práticas para problemas como a miséria, a fome, as epidemias e o meio ambiente, dentre outros, pois são questões que refletem preocupações de fundo com as grandes falhas do projeto moderno relegadas para a sociedade atual. Não que tais engajamentos não sejam verdadeiros e pertinentes, porém, para o autor, essas iniciativas, que portam um inconsciente particular de alívio e de conforto social, podem expressar exatamente a realidade e ênfase em projetos individuais.

Na sociedade contemporânea, não há nada que provoque, no indivíduo, o sentimento de obrigatoriedade. Nem a religião ou mesmo as instituições sociais têm a competência de motivar, no indivíduo, uma suposta responsabilidade sua para com o coletivo. É essa falta de obrigatoriedade que, segundo Lipovetsky (2005b), define o hiperindivíduo na sociedade contemporânea.

Cabe, agora, analisar o segundo fenômeno que dificulta ao Estado dar respostas às demandas sociais, bem como a falta de identificação da sociedade com as instituições governamentais e a própria política representativa: a emergência de um novo tempo/espaço tecnológico. 
0 atual momento histórico, segundo Castells (1999a), é marcado pela Revolução Informacional e Tecnológica, que tem como característica as grandes redes comunicacionais. De acordo com o autor, vivemos em uma era em que a comunicação superou as barreiras impostas pelas distâncias físicas, em que a internet e a sociedade em rede têm permitido a troca de informações de forma instantânea. Formam-se redes independentes das instâncias do mercado ou do governo, o que permite a emergência do que Castells (1999a, p. 23) denominou de "[...] comunicação de massa autocomandada". É comunicação de massa por estar disponível em toda internet e autocomandada porque pode ser iniciada por qualquer indivíduo com acesso à rede.

Castells (1999a, p. 24) afirma que,

[...] uma vez que a política é largamente dependente do espaço público da comunicação em sociedade, o processo político é transformado em função das condições da cultura da virtualidade real. As opiniões políticas e o comportamento político são formados no espaço da comunicação.

A análise de Castells (1999a) permite afirmar que a atual participação da sociedade civil na política atrelou-se às novas tecnologias de comunicação e informação. Sob essa ótica, a participação dá-se pela interatividade no ciberespaço, que garante a transcendência virtual dos aspectos territoriais e culturais locais. Nesse sentido, é necessário destacar o impacto político do aparecimento da internet, que, ao descentralizar os sistemas de comunicação, fez do indivíduo não somente um consumidor, mas também um produtor de informação e controlador do seu meio de comunicação. 
A internet se converteu em um novo espaço, não mais territorial, de expressão política. Por meio das comunidades virtuais, blogs etc., novas formas de participação e de fazer política emergiram sem que ocorressem pelos meios/espaços institucionais tradicionalmente instituídos pelo Estado. Tal fenômeno faz com que a sociedade civil não se identifique mais com esses meios/espaços tradicionais de participação da vida pública, e a atual política representativa tem sua operacionalidade reduzida. Há, portanto, um descompasso entre as instituições políticas democráticas e a própria forma de fazer política na sociedade contemporânea. É precisamente por isso que a participação política contemporânea não se restringe mais no direito ao voto ou em outros direitos formais garantidos por via externa. Esse tipo de participação dava-se na cidadania moderna, tradicional, quando o Estado era o mediador de seu exercício. No atual contexto, as formas de participação dão-se livres de determinadas amarras do Estado mediador, tornando o exercício da cidadania mais ampliado e direto.

Ademais, a tecnologia da informação trouxe o imediatismo, a velocidade, encurtou o tempo e o espaço. A sociedade é a do hoje, do agora. Já o tempo da política e da administração pública é outro, mais lento e burocrático. A burocracia leva a um engessamento da máquina pública e a uma demora em responder à demanda social, resultando em um descrédito por parte da sociedade.

Conclui-se, portanto, que as instituições e práticas típicas do Estado-Nação são correspondentemente debilitadas. Observa-se que a democracia representativa e as formas institucionais de representação cedem lugar à 
participação ativa e direta na internet e aos grupos sociais minoritários e diversos. Também tomam formas mais pluralizadas as identidades coletivas de classe, assim como os aspectos culturais e a própria identidade nacional cedeu lugar a culturas minoritárias. A característica da sociedade atual está mais centrada na pluralidade e diversidade dos grupos multiculturais, fazendo sobressair a diferença e não mais a identificação coletiva de classe, por exemplo. Isso faz com que a identidade torne-se, situacionalmente, fluida e cambiante a cada instante.

Como consequência desse processo tecnológico de produção de individualização, a relação entre o indivíduo e o Poder Público passa a sofrer mutações, o que deflagra novas conformações ao que tradicionalmente se entende como uma relação do Estado com seus cidadãos e, consequentemente, ao atendimento das suas necessidades. E é desse conceito que trataremos no próximo capítulo deste livro. 


\section{OCONCETO \\ DE CDADANAA}

presenta-se, neste capítulo, uma análise sobre o concei-
to de cidadania e os impactos do processo da individualização nas suas formas de exercício.

No Dicionário de Políticas Públicas (FERREIRA; FERNANDES, 2013, p. 145), está afirmado que “[...] os termos cidadão e cidadania geralmente remetem ao indivíduo pertencente a uma comunidade e portador de um conjunto de direitos e deveres". Os autores deixam claro que tal definição é genérica e levantam algumas questões, como: "[...] que direitos são esses? Eles mudam ao longo da história? Em que âmbito são exercidos?" (idem).

Tais perguntas podem ser respondidas ao pontuarmos que partimos, aqui, do pressuposto de que cidadania é um conceito, um exercício e um status construído socialmente e que assume inúmeras formas, a depender dos diferentes contextos sociais. Por ser um conceito historicamente situado, só pode ser compreendido com uma análise do contexto social e político de sua época.

A palavra cidadão vem do latim civitas. 0 conceito remonta à Antiguidade e na civilização grega o termo adquiriu os significados de liberdade, igualdade e virtudes

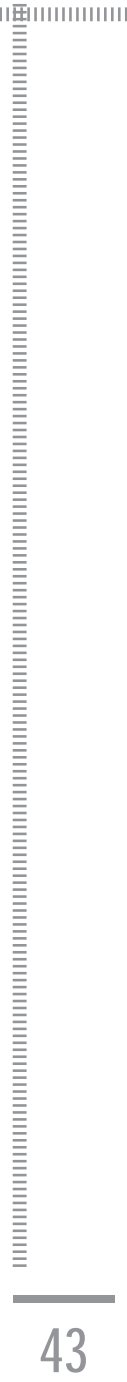


republicanas. Em A Política, Aristóteles (1973) define o que é ser cidadão e quem poderia usufruir desse status. Ser cidadão, explica, significava ser titular de um poder público e participar das decisões coletivas da polis (cidade). Já com relação à igualdade, o status de cidadão limitava-se a um pequeno grupo de homens livres, excluindo-se assim as mulheres, os escravos e os estrangeiros. Apesar de altamente exclusiva, a cidadania clássica, segundo Aristóteles (1973), legou-nos uma dimensão política que atravessa todos os aspectos de vida na polis. Cidadão “[...] é o homem que partilha os privilégios da cidade" (ibidem, p. 88), ou seja, é um indivíduo que participa ativamente das decisões e da vida política da polis. Essa era a concepção de uma cidadania ativa, embora seu exercício estivesse vinculado à condição de ser um homem livre.

Na passagem da Idade Média para a Era Moderna, a ideia de cidadania adquiriu fundamentos filosóficos, especialmente os elaborados pela escola teórica conhecida como contratualista. Foi a partir de tais teóricos que a ideia de um contrato firmado pelos cidadãos com o Estado e a noção de direitos dos homens adquiriram relevância explicativa na formação do Estado-Nação.

Após a Revolução Francesa, a promulgação da Declaração dos Direitos do Homem e do Cidadão trouxe uma dupla perspectiva, a de que os direitos são atribuídos aos homens e cidadãos que vivem no seio de um Estado, e é esse Estado que deve garantir a fruição daqueles direitos. De acordo com Bobbio (2004), a luta pela liberdade, no contexto do estado absolutista francês, marca a emergência do conceito de cidadania moderna e ganha a perspec44 tiva liberal ao ser associada à ideia de liberdade contra o 
poder, o que a diferencia da liberdade na Grécia Antiga, em que era associada à liberdade de participação no poder.

A cidadania moderna diz respeito ao direito da fruição do mundo privado, por meio da garantia da liberdade individual e da possibilidade de delegar sua participação na política a um terceiro, por meio de seu voto no pleito eleitoral. Essa é a diferença que Constant (1985) apresenta ao distinguir a liberdade dos antigos em comparação aos modernos. Sob essa perspectiva, a primeira tem como paradigma a república e a segunda a tradição liberal.

No paradigma moderno de Marshall (1967), cidadania é a capacidade atribuída a um sujeito de ter determinados direitos políticos, sociais e civis, bem como de ele poder exercê-los no interior de um Estado-Nação. Nesse sentido, a cidadania tem seu território definido nas dimensões do Estado nacional e, assim, o cidadão é o indivíduo que tem um vínculo jurídico com o Estado, sendo portador de direitos e deveres fixados por determinada estrutura legal (constituição e leis). Cidadão, por sua vez, é a pertença de um indivíduo a um Estado-Nação, com direitos e obrigações em um específico nível de igualdade. Assim, cabe ressaltar que o princípio de igualdade está presente no conceito de cidadania, visto que é entendido como a condição que garante aos indivíduos, membros plenos de uma comunidade, iguais direitos e deveres, liberdades e restrições.

Marshall (1967, p. 76) elaborou uma teoria sobre o conceito de cidadania, centrada nos acontecimentos britânicos de sua época. 0 autor definiu a cidadania moderna como "[...] um status concedido àqueles que são membros integrais de uma comunidade. Todos aqueles que possuem o status são iguais com respeito aos direitos e 
obrigações pertinentes ao Estado". 0 autor identificou três gerações de direitos no processo de expansão da cidadania: civis, políticos e sociais. Na primeira, no século XVIII, a cidadania era associada à liberdade individual, ou seja, ao direito de ir e vir, de liberdade de consciência e expressão. Na segunda, no século XIX, agregava-se o exercício de participação política, direito ao voto e de ser eleito. Na terceira, no século $\mathrm{XX}$, associava-se às anteriores os direitos que asseguram a possibilidade de condições adequadas de vida - moradia, trabalho, saúde e educação.

Segundo Bobbio (2004), cada geração de direito expressa por Marshall (1967) corresponde a uma concepção de liberdade: "[...] os direitos civis reservam ao indivíduo uma esfera de liberdade em relação ao estado; os direitos políticos lhe garantem a liberdade no Estado; e os direitos sociais significam liberdade através ou por meio do Estado" (BOBBIO, 2004, p. 61). Tal concepção aproxima-se dos princípios liberais de cidadania, que buscam preservar as liberdades individuais do cidadão. Essa visão ainda permanece viva para muitos teóricos contemporâneos.

Inserida no paradigma liberal, Benevides (1994, p. 94) afirma que a "[...] cidadania corresponde ao conjunto de liberdades individuais - os chamados direitos civis de locomoção, pensamento, expressão, integridade física, associação etc.”. Em contrapartida, Chauí (1984) define cidadania pelos princípios da democracia, significando conquista e consolidação social e política. Isso quer dizer que a cidadania tem sido um conceito que reivindica a democracia e está associado ao reconhecimento do outro (ou a sua exclusão e o seu não reconhecimento), bem como conceito atrelado ao discurso dos direitos civis e políticos. A cidadania, nesse contexto, está associada à atuação civil 
e política no seio de uma sociedade democrática. Dessa forma, a cidadania exige constituições de espaços sociais de lutas (movimentos sociais, sindicatos etc.).

Por sua vez, Arendt (1989; 2011) afirma que ser cidadão implica ser membro de uma comunidade e possuir o direito de ter direitos, sendo o primeiro direito o pertencimento a uma comunidade política; já o segundo condiz ao conceito jurídico-legal e traz a noção de ação do indivíduo segundo as leis. Ser membro da comunidade significa poder ter uma participação ativa nos espaços públicos. A compreensão da autora está estritamente vinculada à ideia de pertencimento a um Estado-Nação, noção que será aprofundada mais adiante.

Como pode ser percebido, não é fácil definir o conceito de cidadania. São múltiplas suas variáveis constitutivas e as possíveis interpretações segundo seu contexto social e político. Dessa forma, apresentaremos, a seguir, a nossa proposta de definição do conceito de cidadania.

\section{SOBRE O CONCEITO DE CIDADANIA ESEU EXERĆCIONA SOCIEDADE CONTEMPORÂNEA}

Como já foi exposto, são muitos os componentes que fazem parte do conceito de cidadania. Mas como defini-la?

Cidadania é o status daqueles que são membros de uma comunidade e são por ela reconhecidos. É, também, o conjunto de direitos e deveres que um indivíduo tem diante da sociedade da qual faz parte. Historicamente e genericamente, a cidadania tem uma referência espacial, constituída da relação dos indivíduos com um dado território (organização sociopolítica do espaço). 
Assim, cidadania é uma noção construída socialmente e ganha sentido nas experiências sociais e individuais. Por isso, será aqui compreendida com uma identidade social política. Ora, se identidade pessoal/individual é o conjunto das características e dos traços próprios de um indivíduo, a identidade social são as características que o identificam perante as demais comunidades. E, em certa medida, a consciência de pertencer a algo maior, a um coletivo, a uma sociedade.

Os traços de uma identidade social e política caracterizam uma dada coletividade perante as demais. É o conjunto dessas características sociais que orienta a interação dos membros dessa sociedade com relação às demais sociedades, bem como a diferencia das outras: são as características culturais, linguísticas, religiosas, musicais, culinárias, dentre outras, que representam os hábitos de uma comunidade.

A identidade social é política porque está vinculada ao pertencimento a uma comunidade política, formada/ expressa por um Estado-Nação, com bases legais próprias que regulam a interação do cidadão perante seu Estado e com os demais membros da comunidade. É daí que vem a ideia de direitos e deveres do cidadão. Dessa forma, a cidadania, nesta pesquisa, é compreendida como identidade social e política também por partir do princípio de que o conjunto de práticas políticas, econômicas, jurídicas e culturais definem o indivíduo como membro de uma comunidade.

Sob essa perspectiva, a concepção de cidadania como identidade social e política é constituída por alguns elementos: a) pelos vínculos de pertencimentos; b) pela 
participação política/coletiva; e c) pela consciência de ser portador de direitos e deveres.

\section{a) Vínculo de pertencimento}

É o conceito de Estado-Nação que se configura como central na definição de uma identidade nacional, de pertencimento coletivo e de inclusão em determinada comunidade política. Por sua vez, o que faz o liame para articular esse espaço de Estado-Nação é a consolidação de uma cultura nacional homogênea que congrega e solidifica o sentimento de pertença. A consolidação dessa cultura nacional depende da idealização e do reconhecimento de fatos, lendas, tradições, costumes e mitologias diversas a respeito do passado, ocorridos ou concebidos no território delimitado e ocupado por essa sociedade. Em síntese, a identidade nacional é uma criação coletiva que dá sustentabilidade, organicidade e durabilidade à ideia do Estado-Nação.

A expressão nação, que anteriormente era utilizada para referir uma comunidade formada por indivíduos com ascendência comum, passou a ser compreendida como uma instituição politicamente integrada sob a forma da organização estatal, criando, assim, uma forte relação entre cidadania e identidade. Segundo Habermas (1994), o nacionalismo teve forte influência não negligenciável na criação das condições que permitiram o estabelecimento da cidadania.

É nesse sentido que Santos (1993), em consonância com Habermas (1994), sugere que, naquilo que se refere à definição das culturas nacionais, o papel do Estado é 
dúplice: por um lado, diferencia a cultura do território nacional em face do exterior; por outro lado, promove a homogeneidade cultural no interior do território nacional. As nações modernas procuravam homogeneizar culturalmente seus cidadãos, promovendo sua unificação linguística, religiosa e de costumes, e criavam direitos exclusivos, símbolos e rituais que os identificavam como membros de uma só nação. $O$ Estado-Nação, portanto, pode ser entendido como uma entidade cultural e política que promove sentido à identidade nacional.

Assim, no sentido mais estreito e de acordo com o senso comum, cidadania poderia ser reduzida à nacionalidade, isto é, a uma afiliação formal de indivíduos aos Estados-Nacionais. Essa concepção estaria relacionada ao sentimento de lealdade perante um grupo, uma comunidade, a sociedade civil, o Estado, o que faz com que a cidadania esteja associada a uma identificação subjetiva e a um sentimento de pertença a uma dada sociedade. Assim, a cidadania é uma forma institucionalizada de afiliação e constitui uma expressão de pertença plena e formal. Engloba uma série de transações recíprocas que tecem laços entre o cidadão - indivíduo - e o Estado, e é a percepção de pertencimento a um Estado, legitimada pelo reconhecimento público desses laços, que confere a identidade de cidadão.

A visão de Arendt (1989) reforça a importância dessa dimensão no conceito de cidadania. A autora afirma que o não pertencimento a uma comunidade acarretaria a ausência de um status político de um indivíduo e, portanto, a privação dos direitos assegurados por um Estado, denominados pela autora como os apátridas - os povos sem Es50 tado. Tais indivíduos, ao terem sua nacionalidade negada, 
deixam de ser reconhecidos como integrantes do Estado-Nação e chegam até mesmo a não serem integrantes do mundo, visto que não possuem vínculos com qualquer comunidade política, como foi o caso dos judeus alemães na Segunda Guerra Mundial, "[...] que não dispunham de governos que os representassem e protegessem e, por isso, foram forçados a viver ou sob as leis de exceção dos Tratados das Minorias [...] ou sob condições de absoluta ausência de lei" (ARENDT, 1989, p. 302). O significado de cidadania para a autora está, dessa maneira, intrinsecamente vinculado ao pertencimento a uma comunidade, isto é, a um Estado-Nação.

Todavia, no contexto de uma cultura global, cenário da sociedade contemporânea, deve-se encarar que a multiplicidade de culturas e de formações identitárias, dificilmente enquadráveis no seio de uma cultura uniforme, enfraquece a identidade nacional constitutiva do Estado-Nação. Além disso, como afirmado no capítulo anterior, o atual processo de desterritorialização, como consequência do fenômeno de globalização, vem enfraquecendo a soberania do Estado-Nação e este se vê no desafio de adequar-se a uma realidade multicultural e global.

Pode ser argumentado que, frente à análise de uma sociedade globalizada, há correntes teóricas que afirmam a desvinculação entre cidadania e nacionalidade, utilizando como exemplo o caso da União Europeia (UE) (VIEIRA, 2013; CASTELLS; 2000). Logicamente, a instauração da UE conferiu novos direitos e status legal aos indivíduos que fazem parte dos países que a compõem, que são considerados cidadãos da União Europeia. Entretanto, para que se possa fazer parte da comunidade da União Europeia, é necessário, primeiramente, ser cidadão de um 
Estado-Nação que a componha, o que reforça a importância do vínculo de pertencimento mesmo nesse contexto.

Compartilhamos, no entanto, a compreensão de que, a despeito do enfraquecimento do Estado-Nação frente à globalização, a noção de identidade nacional continua presente. Podemos citar, como exemplo, as necessidades de vistos de estudantes/turismo/trabalho, seja nos pedidos de dupla/tripla cidadania, seja nos pedidos de asilos de refugiados. Essa identidade nacional pode não estar baseada na identidade cultural - noção moderna de nacionalidade -, mas, sim, no vínculo jurídico com o Estado-Nação.

Nesse sentido, a cidadania ainda pode ser pensada como um instrumento institucional através do qual os Estados incluem ou excluem os indivíduos que desejam/ almejam participar de determinada comunidade nacional. Se por um lado a cidadania gera um vínculo e um sentimento comum de pertença a uma comunidade política, por outro, sua falta acarreta inúmeras dificuldades para aqueles que não são considerados cidadãos, como os imigrantes ilegais que sofrem o preconceito, a dificuldade de deslocamento territorial, assim como a falta de acesso aos direitos. Aqui, podemos também citar os casos dessa verdadeira transumância humana da atualidade, uma verdadeira catástrofe a afligir hoje a humanidade - constituída pelas recentes levas de refugiados, seja por razões de pobreza, seja pela fuga de conflitos bélicos do Oriente Médio, como os sírios, seja pela busca por melhores condições de vida e trabalho, como acontece com haitianos, bolivianos e, mais recentemente, venezuelanos também na América Latina, aqueles que se deslocam do Norte da África em direção à Europa, e muitas outras ondas migratórias. 


\section{b) Participação política/coletiva}

Tendo Habermas (1994) como referência, entende-se que a cidadania nunca esteve conceitualmente ligada apenas à ideia de identidade nacional, mas que ela também está vinculada à práxis com que os cidadãos exercem seus direitos civis e políticos. Cidadania não é apenas um critério passivo de pertença a uma comunidade nacional de direitos e deveres conferidos pelo Estado. É também uma prática social que os indivíduos assumem para além do Estado, por meio de instituições da sociedade civil e de ações civis, tal como expresso por Chauí (1984).

Ao adicionar o elemento participação política/coletiva, o conceito de cidadania torna-se mais complexo e pode ser utilizado não apenas para referir o estatuto legal do indivíduo e a sua forma de pertencimento a uma comunidade nacional, mas também para definir sua participação ativa na esfera pública. Desse modo, acrescida da dimensão da participação política coletiva, parte-se do pressuposto de que o vínculo com o Estado-Nação é apenas um dos itens/componentes que compõe o conceito de cidadania, e não o seu único elemento definidor.

Sob essa perspectiva, o exercício da cidadania permite a práxis da negociação com o Estado e a participação política da comunidade, estando o exercício da cidadania vinculado fundamentalmente a um Estado democrático.

A democracia é aqui entendida não apenas como um regime político com partidos e eleições livres, mas, sobretudo, como forma de existência social. 0 regime político democrático possibilita a formação de uma sociedade aberta, em que se permite a criação de novos direitos, a 
participação popular nas decisões políticas e a existência de movimentos sociais. Um Estado democrático é aquele que considera o conflito como legítimo e trabalha em prol de um bem comum e da instituição de direitos universais (BENEVIDES, 1994).

Nesse caso, as leis e os direitos de cidadania são resultados de negociações, contestações e lutas entre o Estado e a sociedade civil. A cidadania é ativamente construída, exercida e interpretada pelo Estado e pelas instituições da sociedade civil. A cidadania, definida pelos princípios democráticos, é fundamentalmente um exercício, uma prática que se constitui na criação de espaços sociais de lutas - como os partidos políticos e movimentos sociais - e na definição de instituições para a expressão política como partidos, organizações, conselhos populares etc. -, significando necessariamente conquistas e consolidações sociais e políticas (VIEIRA, 2013). 0 exercício da cidadania, portanto, está vinculado ao desenvolvimento de uma sociedade democrática.

No ambiente da modernidade, o modelo de política esteve sob o pêndulo do dicotômico do jogo de esquerda-direita, de acordo com Bauman (2001). Esse jogo oscilava entre os propósitos e os anseios de perspectivas das revoluções burguesa ou socialista. Cada parte desse espectro político propunha seu próprio processo de avanço da sociedade. Assim, parlamentos, partidos e sindicatos eram os verdadeiros atores sociais da política e sua atuação refletia sua ideologia de classe. Essa configuração política estava de acordo com os paradigmas da modernidade, segundo os quais a política representativa determinava sua ação. Assim, na sociedade democrática, a ação política do cidadão moderno dá-se nas urnas em períodos eleitorais, 
por meio do seu direito ao voto e, em momentos excepcionais, em plebiscitos e conferências populares (a forma da organização partidária como componente viabilizador da representação).

Porém, com a emergência dos novos paradigmas da sociedade contemporânea, o modelo político moderno não responde às novas exigências e às transformações sociais. Os problemas sociais da nova modernidade são mais complexos, com mais variáveis, menos hegemônicos, mais individuais e, por vezes, desterritorializados. Dizem respeito às condições de vida do indivíduo contemporâneo, que fogem da simples dicotomia direita-esquerda e de suas ortodoxias. A política, ao menos no cotidiano, não é mais a dos grandes sistemas ou soluções, ela representa um espaço em defesa da voz das novas identidades, das afinidades profissionais, estéticas e minoritárias.

Dessa maneira, o esvaziamento da participação popular nas instituições burocráticas modernas e o descrédito da sociedade em relação ao Estado, coloca em xeque as categorias do pensamento político clássico, provocando, assim, a fragilidade da política de Estado em responder às demandas sociais e falta crescente de identificação das sociedades contemporâneas com as instituições governamentais.

Segundo Lipovetsky (2005a), o individualismo contemporâneo não anula as formas coletivas de participação, apenas altera seu teor. Ao contrário do que muitos políticos e teóricos afirmam - que hoje todos estariam, de alguma maneira, desorganizados e mesmo desinteressados da participação política -, cresce na sociedade contemporânea a voz da sociedade civil, por meio de novas formas de participação e expressão política em outros meios não 
institucionalizados. A política da atualidade efetiva-se nas ações da política-vida ${ }^{2}$ de Giddens (2002), da subpolítica ${ }^{3}$ de Beck (1997) e na micropolítica ${ }^{4}$ de Guatarri e Rolnik (2005).

A política transfigura-se na pluralidade constitutiva dos sujeitos sociais e políticos, o que favorece o surgimento de novos grupos e atores individuais que lutam pelos direitos de cidadania e reconhecimento de múltiplas identidades. Assim, as formas de representação política da democracia moderna não espelham a atual diversidade da sociedade, o que causa a atual desilusão e apatia da sociedade com os partidos e plataformas políticas.

De qualquer forma, como já exposto, isso não significa o fim da política, mas sim uma transformação na sua forma de ação. É uma reinvenção segundo os paradigmas da sociedade contemporânea. 0 campo de ação, inserido nesse novo tempo-espaço, irrompe para além das hierarquias formais do Estado moderno. A política atual penetra os poros da sociedade, nos grupos, nas redes sociais, nas demandas individuais. Ela se expressa no micro e de forma descentralizada.

\footnotetext{
2 Para Giddens (2002, p. 197), o conceito de política-vida “[...] refere-se a questões políticas que fluem a partir dos processos de auto-realização em contextos pós-tradicionais, onde influências globalizantes penetram profundamente no projeto reflexivo do eu e, inversamente, onde os processos de auto-realização influenciam as estratégias globais".

${ }^{3}$ Para Beck (1997), o conceito de subpolítica significa o espaço em que os indivíduos, apesar de não inseridos no sistema político formal, interferem na política, quer por meio de questões reflexivas, quer de forma direta. Tais ações podem ocorrer em vários campos, seja na saúde, na tecnologia ou no direito.

${ }^{4}$ A micropolítica procura desmistificar o poder de forma centralizada, mostra seu enraizamento e penetração no cotidiano da vida dos sujeitos, de forma capilar. Apresenta o poder não apenas como negativo, coercitivo, opressor, mas também como positivo e produtor de saberes, subjetividades, ideologias, agenciamentos.
} 
Ademais, não podemos esquecer a transformação na política causada pelo aparecimento da internet 2.0, ou seja, a participação e a contribuição nas redes sociais criam novas formas de ações individuais e coletivas no que pode ser chamado de net-ativismo. São formas de exposição, discussão e denúncias com ampla magnitude e visibilidade permitidas pelo imediatismo da velocidade das redes. Tratam-se de plataformas coletivas para divulgar posições políticas, opiniões e sentimentos de grupos e indivíduos. Dessa maneira, a internet cria uma nova forma de ação política, por vezes dissonantes das instituições políticas modernas.

Assim, podemos considerar que a estrutura de delegação política, hierárquica e representativa, tal como posta em prática no nascimento do Estado moderno, com base nos ideais filosóficos, vem chegando a um ponto de saturação. Entretanto, isso não significa que as formas de representação tenham desaparecido, mas o fato é que a energia social desloca-se em direção a outras estruturas e novas formas de mediação. As redes, e particularmente as ferramentas sociais, levam-nos a essa transfiguração das ações, em que a participação dá-se por estruturas mais diretas, desterritorializadas e sem hierarquia. É por isso que as forças e as instituições políticas tradicionais modernas estão cada vez mais em declínio e esvaziadas, por não atenderem às atuais demandas sociais e as formas de participação contemporânea.

A sociedade civil atual fortalece sua ação política por meio de novos movimentos sociais e das redes sociais virtuais. Ela é concebida aqui como a esfera da interação social entre a economia e o Estado. "O papel político da sociedade civil não está diretamente relacionado à 
conquista e controle do poder, mas à geração de influência na esfera pública cultural" (VIEIRA, 2013, p. 47). A política da sociedade civil não se resume às formas institucionais e normais de participação, como votar, afiliar-se a partidos políticos ou associar-se a grupos. Trata-se do produto de atores coletivos que se autoconstituem na forma de movimentos sociais, que surgem para defender novos direitos, de reconhecimento, de mudanças e em defesa de espaços de mais liberdade.

De acordo com Gohn (2008), até o início do século $\mathrm{XX}$, o conceito de movimentos sociais aplicava-se tão somente à organização e à ação dos sindicatos. Depois de 1960, novos movimentos sociais surgiram, especialmente na Europa, Estados Unidos e América Latina, no momento em que a abordagem clássica marxista passava por processo de crítica e revisão. As principais críticas ao marxismo baseavam-se na seguinte questão: alguns teóricos marxistas priorizavam a análise de categoria de luta de classes, através de uma leitura dicotômica (burguesia-proletariado), sem considerar o momento histórico-social e as transformações do capitalismo contemporâneo.

Dentre os muitos críticos da análise marxista, destacam-se Touraine (1995) e Castells (2000), cujas aproximações resultaram na teoria dos novos movimentos sociais. Para esses teóricos, os novos movimentos surgem como organizações de massa de trabalhadores, jovens, mulheres etc. Com efeito, no contexto dessas transformações, fazem-se presentes novos atores, como os chamados movimentos sociais culturais, feministas, pela livre orientação e diversidade sexual, ambientalistas, dentre outros.

Dessa maneira, prossegue o impulso da concepção neoliberal da sociedade civil e a emergência das chamadas 
organizações não governamentais - as ONGs no terceiro setor -, que ganharam força na virada do século XXI. Nesse mesmo contexto, surgem também os movimentos que criticam tanto a ânsia pelo lucro e a competitividade no capitalismo, como também questionam os vícios e erros que o socialismo real implantara na Europa Oriental.

Em meados do fim século XX e início do XXI, com os novos marcos contemporâneos e o aumento do individualismo e do consumo, ocorreram significativas transformações no âmbito dos movimentos sociais. Surgiram novos movimentos relacionados a questões como: direitos humanos, cultura, orientação sexual, cidadania, etnia/ raça (negros, indígenas), movimento feminista e de mulheres. $O$ fenômeno da globalização e de informatização da sociedade levou os novos movimentos a diversificarem-se e a tornarem-se mais complexos.

Segundo Goss e Prudencio (2004, p 81), nos dias atuais, observa-se o fortalecimento dos movimentos sociais de natureza identitária. No seio do paradigma individualista, esses movimentos lutam pelo "[...] reconhecimento de suas particularidades e diferenças, ou seja, por questões específicas". Assim, a reconstrução da identidade pessoal dá-se pelo reconhecimento da dissociação dos elementos que formavam uma experiência integrada.

Diante da impossibilidade de localizar o adversário (não mais identificado como uma classe, um partido ou mesmo um Estado), o chamamento ao sujeito é um processo de identificação, e não mais de identidade, e se evidencia/manifesta onde a lógica das técnicas e dos mercados entra em conflito com a lógica do sujeito. Por isso, muitas das explicações paradigmáticas nos estudos da segunda 
metade do século XX necessitam de revisões ou atualizações ante a emergência de novos sujeitos sociais e cenários políticos. (GOSS; PRUDENCIO, 2004, p. 80).

Há uma nova gramática política sendo formada no exercício da cidadania, mais direta e menos hierárquica, ou seja, sem ser necessariamente por meio da institucionalização partidária, ela é mais fluida e identitária. Não há mais a rigidez que os movimentos sociais modernos apresentavam. Os atuais movimentos são múltiplos e mais complexos.

\section{c) Consciência de ser portador de direitos e deveres}

Bobbio (2004), afirma que a ideia dos direitos dos homens deriva da inversão de perspectiva na representação da relação política, isto é, na consolidação da relação estado/cidadão em vez do soberano/súdito:

[...] relação que é encarada, cada vez mais, do ponto de vista dos direitos dos cidadãos não mais dos súditos, e não do ponto de vista dos direitos do soberano, em correspondência com a visão individualista da sociedade, segundo a qual, para compreender a sociedade, é preciso partir de baixo, ou seja, dos indivíduos que a compõem, em oposição à concepção orgânica tradicional, segundo a qual a sociedade como um todo vem antes do indivíduo. (BOBBIO, 2004, p. 4).

A ideia moderna de direito, portanto, é inerente ao conceito de indivíduo, um ente que tem valor em si mesmo, dotado de direitos naturais. A matriz individualista 
tem como base o fundamento de que o indivíduo antecede o Estado e a sociedade e, dessa forma, contrapõe-se à concepção orgânica, segundo a qual a sociedade é um todo. A máxima dessa concepção pode ser identificada na frase: todos nascem livres e iguais. Isso quer dizer que o indivíduo é concebido como um ser de direitos e que esses direitos antecedem a organização social e política, bem como têm prevalência sobre os deveres. No prenúncio da modernidade, como pode ser percebido, houve uma mudança qualitativa nos termos que se referem à concepção de homem, sociedade e Estado.

As teorias jusnaturalistas, desenvolvidas nos séculos XVII e XVIII, apesar das diferenças entre autores como Hobbes (1999) e Locke (2006), têm em comum a caracterização dos homens como sujeitos portadores de direitos, entes individuais e autônomos. De fato, a crença moderna é a de que os direitos do homem correspondem a uma qualidade intrínseca ao próprio homem.

De acordo com Bobbio (2004), a concepção individualista, comumente, incitou discórdias e rupturas na ordem sociopolítica constituída e, portanto, custou a abrir caminho. Hobbes (1999) mostra essa perspectiva do individualismo ao apresentar o estado de natureza de forma tão negativa, em que os indivíduos viviam sem relações e em contradições de interesses. Em contrapartida, o Estado é apresentado como um corpo ampliado, no qual o soberano é a alma de um corpo artificial que une esses indivíduos. Apesar dessa visão negativa de Hobbes (1999), a concepção individualista vem ganhando corpo e força desde a modernidade. Nessa concepção, o indivíduo está em primeiro lugar e, depois, vem o Estado, já que este é construído pelos indivíduos: 
Nesta inversão entre indivíduo e Estado, é invertida também a relação tradicional entre direito e dever. Em relação aos indivíduos, doravante, primeiro vêm os direitos, depois os deveres; em relação ao Estado, primeiro os deveres, depois os direitos. A mesma finalidade ocorre com o Estado, a qual para o organicismo é concórdia ciceroniana, ou seja, a luta contra as facções que, dilacerando o corpo político, o matam, para o individualismo, é o crescimento do indivíduo, tanto quanto possível livre de condicionamentos externos. (BOBBIO, 2004, p. 56-57).

Bobbio (2004) utiliza essa inversão para fundamentar o reconhecimento dos direitos dos homens, ao afirmar que, quando esse reconhecimento amplia-se para o poder entre príncipe e súdito, nasce o chamado direito público subjetivo, que caracteriza o Estado de direito. De acordo com o autor, é com o nascimento do Estado de direito que ocorre a passagem da centralidade do príncipe para o cidadão. Assim, o Estado de direito é, para ele, o Estado do cidadão.

Nesse novo paradigma, a sociedade e o Estado não são fenômenos dados, mas sim constituídos pelo próprio homem. São concebidos como criações humanas, resultantes de um pacto entre os indivíduos. A desigualdade e o poder ilimitado deixam, pois, de ser justificados como naturais, isto é, como decorrentes da ordem natural das coisas, ou, ainda, como materializações de uma vontade extraterrena. Os arranjos sociais e políticos tornam-se, portanto, passíveis de contestações e sujeitos à intervenção do homem que os constituiu.

Além da igualdade de direitos naturais, deriva daí, 62 também, uma nova concepção de liberdade. A liberdade, 
nesse novo paradigma liberal, deixa de ser concessão ou característica de uma camada social ou de um estamento, mas converte-se em um atributo do próprio homem. Locke (2006) afirmou que o homem é definido por sua vida, sua liberdade e seus bens. Dessa forma, toda e qualquer desigualdade provocada pelo arranjo social passa a ser entendida como um resultado do acordo realizado entre indivíduos, ou seja, o homem passa a ser responsável por seus próprios fracassos e desigualdades.

Os preceitos filosóficos forneceram os fundamentos para uma nova arquitetura social. Esses arranjos encontraram sua manifestação mais explícita na codificação da igualdade entre os homens a partir de normas legais, ou seja, na formalização dos direitos. Esses direitos constituem e delimitam a cidadania moderna. Ser cidadão significa ser detentor de direitos e deveres que os outros, os não cidadãos, não possuem.

A doutrina dos direitos do homem, concebida nos séculos XVII e XVIII, encontrou seu primeiro momento de eficácia na Declaração de Independência dos Estados Unidos, de 1776, na Declaração dos Direitos do Homem e do Cidadão, de 1789, e, posteriormente, nas constituições liberais que incorporaram os fundamentos dos direitos naturais.

Marshall (1967), em seu estudo clássico sobre cidadania, tomando como referência empírica a história inglesa, aponta a existência de três conjuntos de direitos: civis ou individuais, políticos e sociais. No caso, esses direitos foram progressivamente conquistados, sendo possível estabelecer um período histórico correspondente a cada um deles:

- direitos civis ou individuais: são os direitos de reunião, de expressão, de opinião, de pensamento e de fé, de ir e vir, de celebrar contrato, de acesso 
à justiça, ao trabalho, à propriedade, dentre outros. A construção dessa dimensão dos direitos deu-se no século XVIII em contexto europeu.

- direitos políticos: são os direitos de votar e ser votado, de participar do poder político como membro de um organismo investido de autoridade política ou mesmo como um eleitor. Esses direitos foram, também, conquistados na Europa, no século XIX.

- direitos sociais: são os direitos de acesso aos benefícios da riqueza coletiva gerada, como saúde, educação, previdência etc. É o direito a ter o mínimo de bem-estar econômico e segurança. É uma conquista também europeia do século XX.

A consagração em lei desses conjuntos de direitos traduziu a definição e a busca de igualdade para a sociedade que os reconhecia. Isto é, o direito civil estabeleceu que, a despeito das desigualdades sociais e econômicas, todos são iguais perante a lei e o Estado. 0 direito político estabelece que, apesar das diferenças quanto à riqueza, os cidadãos são iguais no que diz respeito à participação política e escolha de seus governantes. Quanto aos direitos sociais, estes pressupõem a existência de uma desigualdade social e são constituídos com o objetivo de amenizá-la.

Dessa forma, os direitos civis e políticos têm por base o indivíduo, e exigem, para a sua efetivação, a mediação do poder público. Já os direitos sociais, também conhecidos como direitos de segunda geração, requerem uma política pública que reconheça a exclusão de alguns ou muitos -, e objetiva uma justiça distributiva. Posto isso, torna-se necessário um Estado forte e atuante para que se concretize o acesso à saúde, à educação, à moradia, à alimentação etc. (BOTELHO; SCHWARCZ, 2012). 
Segundo Bobbio (2004), a luta histórica por direitos foi marcada por uma mudança na busca da liberdade, que passa não só pelo desejo de que o Estado não oprima, não exorbite, não agrida - o que constitui a defesa da liberdade negativa, isto é, a liberdade do indivíduo contra o Estado -, mas de que ele tenha uma ação positiva, a de garantir direitos como o de representação política e da participação na riqueza coletiva.

Essa nova busca de liberdades positivas está estreitamente ligada ao aparecimento de novos atores sociais no cenário político: enquanto a burguesia ansiava por um Estado mínimo que a deixasse livre para desenvolver suas riquezas, advogando, portanto, pela liberdade negativa, $\mathrm{o}$ proletariado, ao tornar-se cidadão, passou a postular ao Estado a tarefa de ser o distribuidor das riquezas coletivas, advogando, então, pela liberdade positiva.

É claro que as transformações socioeconômicas, a intensificação dos meios de comunicação, o aumento do individualismo e do consumo produziram mudanças na organização da vida humana e das relações sociais e, dessa forma, criaram um terreno fértil para o aparecimento de novas demandas por mais direitos positivos e negativos. 0 elenco dos direitos do homem não é estático, ele se modificou e continua modificando-se conforme a mudança das condições históricas, isto é, da mudança de interesses, das transformações no Estado, das técnicas, dos paradigmas dentre outras situações (BOBBIO, 2004).

Segundo Botelho e Schwarcz (2012, p. 11), os direitos civis, políticos e sociais não findam a lista de direitos que compõem a categoria de cidadania ou os conteúdos e limites de igualdade. "Nas últimas décadas, a eles foram acrescidos os chamados direitos de terceira geração, que 
se referem não mais a indivíduos, mas aos grupos”. Esses são os direitos do consumidor, de crianças, de idosos, de mulheres, de homossexuais, de negros, das minorias. "Nesse novo contexto, marcado pelos direitos sociais, modifica-se inteiramente o perfil do Poder Público e também o da justiça estatal. Trata-se, a partir de então, de garantir não apenas as liberdades negativas, mas também de assegurar as liberdades positivas" (idem).

De acordo com Lipovetsky (2005a), a sociedade contemporânea caracteriza-se por uma tendência global de aumentar a oportunidade das escolhas individuais e privilegiar a diversidade. Da mesma forma que os indivíduos são plurais e distintos, tudo passa a ser individualizado e tendo como foco o indivíduo personalizado; há, certamente, uma dificuldade em aceitar as políticas públicas homogêneas.

Os cidadãos, como sujeitos coletivos, pulverizaram-se em suas características individuais, evidenciando suas particularidades: mulher, negro, judeu ou homossexual. 0 cidadão exige, assim, direitos e políticas específicas, inscritas nos campos setoriais da diversidade existente na sociedade. Devido ao pluralismo social, aumenta, na sociedade contemporânea, a demanda por novos direitos e reconhecimentos identitários.

A multiplicação contemporânea dos direitos, segundo Bobbio (2004, p. 63), ocorreu de três modos:

[... a) porque aumentou a quantidade de bens considerados merecedores de tutela; b) porque foi estendida a titularidade de alguns direitos típicos a sujeitos diversos do homem; c) porque o próprio homem não é mais considerado como um ente genérico, ou homem em abstrato, mas é visto na especificidade ou na concretude de suas 
diversas maneiras de ser em sociedade, como criança, velho, doente etc.

Em suma, mais bens, devido ao desenvolvimento do capitalismo e, portanto, do consumo, e mais status de indivíduo, devido à radicalização da individualização, identidade e diversidade. Quanto à radicalização do indivíduo, a passagem ocorreu do homem genérico para o homem específico, tomado por critérios de identidade e diversidade, segundo critérios de diferenciação, o que exige reconhecimento e políticas específicas. Emergem, assim, novos sujeitos, cada um com sua especificidade, que reivindicam tratamentos iguais, segundo suas diferenças. E essa é a grande dificuldade atual do Estado. Como garantir tantos direitos distintos e por vezes contrários?

0 problema fundamental em relação aos direitos na contemporaneidade não é tanto o de fundamentá-lo e declará-lo, mas o de protegê-lo. Para garanti-lo, não basta declará-lo. Trata-se de um problema que não é filosófico, segundo Bobbio (2004), mas sim político. Sua dificuldade está na inexequibilidade por parte das instituições políticas. 0 problema real é enfrentar quais as medidas efetivas para a proteção desses diretos.

Segundo, Bobbio (2004, p. 42), os direitos constituem uma categoria heterogênea, ou seja, o seu conjunto passou a conter direitos que são incompatíveis, quais sejam, os “[...] direitos cuja proteção não pode ser concedida sem que seja restringida ou suspensa a proteção de outros". Isso significa que alguns direitos buscam a liberdade e a proteção da intervenção do poder estatal e outros pedem a intervenção do Estado para poder se efetivar. Nos termos de Bobbio (2004), essa é a contradição entre os modelos liberais e socialistas. 
Tais direitos só valem no âmbito do Estado que os reconhece. "Embora se mantenha, nas fórmulas solenes, a distinção entre direito do homem e do cidadão, não são direitos do homem e sim apenas do cidadão, ou, pelo menos, são direitos do homem somente enquanto são direitos do cidadão deste ou daquele Estado em particular" (BOBBIO, 2004, p. 29).

Além dos direitos promulgados no interior de um Estado-Nação, cabe aqui mencionar os Direitos Humanos. A Declaração Universal dos Direitos Humanos, promulgada pelas Nações Unidas em dezembro de 1948, teve como um dos fatores precursores os danos causados pela Segunda Guerra Mundial. Nesse sentido, a declaração emergiu como um instrumento na busca de "[...] um mundo em que os todos gozem de liberdade de palavra, de crença e da liberdade de viverem a salvo do temor [...]" (ONU, 1948, p. 3). Considerou-se que os direitos humanos devessem ser "[...] protegidos pelo império da lei, para que o ser humano não seja compelido, como último recurso, à rebelião contra a tirania e a opressão" (idem).

Faz-se necessário ressaltar que a declaração foi um ato de internacional de reconhecimento por parte de todos os Estados-Nações que compunham a Organização das Nações Unidas (ONU). Ao contrário dos civis, sociais e políticos, os direitos humanos não são fruto da legislação de uma nação, mas, sim, são concebidos para toda a humanidade, independentemente de sua nacionalidade, somente pelo fato de constituírem-se como ser humano. Entretanto, Arendt (1989) afirma que a garantia desses direitos, também, está vinculada à primeira dimensão do 
conceito de cidadania, a de pertencimento. A eficácia dos diretos humanos depende de mecanismos presentes no interior de um Estado para garanti-los aos seus cidadãos. Isso quer dizer que os apátridas, que não possuem qualquer vínculo com o Estado, estão destituídos da proteção que esse possa assegurá-los e, por não serem mais um indivíduo político, não têm a quem reivindicar seus direitos (ARENDT, 1989; LAFER, 1988).

Outra questão importante a ser elucidada é em relação aos deveres dos cidadãos. A função primária da lei é a de se fazer cumprir, restringir e corrigir ações. As leis são essencialmente imperativas e visam obter o comportamento desejado ou evitar o indesejado. Dessa forma, podemos afirmar que "[...] o direto e o dever são o verso e o reverso de uma mesma moeda" (BOBBIO, 2004, p. 53).

De acordo com Bobbio (2004, p. 54) “[...] a relação política por excelência é a relação entre governantes e governados, entre quem tem o poder de obrigar, com as decisões, os membros do grupo e os que estão submetidos a essa decisão". 0 objeto da política clássica foi sempre o bom governo ou o mau governo. As referências às atividades típicas de um governante são as de guia, cabendo-lhe conduzir à sua meta os indivíduos que governa. 0 indivíduo, nesse caso, é essencialmente um objeto de poder do governante; mais do que seus direitos, a política trata de seus deveres, dentre os quais é ressaltado como principal o de obedecer às leis. Segundo Bobbio (2004), o sujeito ativo desta relação não é, seguramente o indivíduo provido de seus direitos naturais, mas o povo em sua totalidade. 


\section{TIPOLOGIA DA CIDADANA}

Aqui, partiremos do pressuposto de que, apesar de a identidade social política ideal ser constituída pelos três elementos - vínculo de pertencimento, participação política/coletiva e consciência de ser portador de direitos e deveres -, essa composição não é rígida. Ela pode ser composta de um, dois ou três elementos. 0 único elemento essencial para sua constituição é o primeiro, o de pertencimento a uma comunidade, que se justifica pela afirmação de Nogueira (1999, p. 70):

[...] cidadania e Estado moderno nasceram juntos, reforçam-se reciprocamente: a cidadania cresceu quando encontrou abrigo e anteparo estatal, isto é, quando converteu em um conjunto de direitos dependentes da devida normatização e das garantias estabelecidas pelo Estado e no Estado.

O pertencimento a um Estado ainda é um quesito necessário para o status e o exercício de cidadania, ou seja, esse elemento garante o pertencimento e o reconhecimento de ser um cidadão.

Com exceção do primeiro elemento, os demais são variáveis constitutivas para a formação da cidadania plena. 0 primeiro elemento garante o pertencimento, o segundo garante o exercício político da cidadania, e o terceiro garante os direitos e os deveres do cidadão, isto é, sua proteção social, civil e política. Assim, as duas últimas constituem as dimensões essenciais para possibilitar o exercício da cidadania. Em outras palavras, os três elementos seriam partes constituintes de um tipo ideal de 
cidadania, mas não do conceito definidor de cidadania. Dessa forma, partiremos do pressuposto de que a combinação desses elementos conforma três grupos de cidadãos: cidadão pleno ${ }^{5}$, cidadão politicamente passivo e cidadão tutelado. Essa formulação diferencia-se de outras, pois tem por substrato não apenas a discussão teórica sobre cidadania, mas, sobretudo, busca incorporar a dimensão do seu exercício, de fato, pelos diferentes cidadãos.

o primeiro grupo, o do cidadão pleno, é constituído pelas três dimensões, ou seja, o pertencimento, a participação política/coletiva e o detentor de direitos e deveres. A principal característica desse grupo é a de serem cidadãos politicamente ativos, com consciência de seus deveres, e que lutam pela garantia e ampliação dos direitos; por isso, estão em constante articulação com o governo e com outras instituições sociais.

O segundo grupo, o do cidadão politicamente passivo, é composto pelas dimensões de pertencimento e detentor de direitos e deveres. Esse grupo é caracterizado pelos que não participam da vida política, seja por apatia ou descrença em relação à política e às instituições políticas atuais, ou por se encontrarem impossibilitados. Apesar de

${ }^{5}$ Carvalho (2015) afirma existir três tipos de cidadãos brasileiros: o cidadão pleno, que é detentor dos três direitos (civis, políticos e sociais); o cidadão incompleto, que é detentor de ao menos um dos direitos; e o não cidadão, que não se beneficia de qualquer dos direitos. Para o autor, há um vínculo entre alguns direitos, como o civil e o político. Se não há a garantia do direito civil, como a liberdade, não se pode garantir o direito político. Entretanto, o direito político, como a possibilidade de escolher um governante, não é garantia de direitos sociais. Tomamos emprestada a categoria cidadão pleno, que é definida por ser "[...] titular dos três direitos" (CARVALHO, 2015, p. 9). Entretanto, ampliaremos seu significado ao acrescentarmos mais duas dimensões: a de pertencimento e a de participação política/coletiva. 
não ser ativo politicamente, tem conhecimento de seu pertencimento e de como usufruir e garantir seus direitos.

0 terceiro, o do cidadão tutelado, é constituído apenas pelo primeiro elemento, o de pertencimento. Os cidadãos desse grupo são caracterizados por não conseguirem exercer seus direitos políticos e por não terem garantidos seus direitos como cidadãos. Em sua maioria, são indivíduos considerados inimputáveis, isto é, não responsáveis por seus atos, e encontram-se tutelados pelo Estado ou por outro indivíduo responsável por eles. São os indivíduos em situação de grande vulnerabilidade social, como os doentes mentais. Estes, na maioria das vezes, são considerados cidadãos apenas pelo pertencimento a um Estado-Nação, pois nem sempre possuem condições de garantir sozinhos os seus direitos, deveres e o livre exercício político.

É possível inferir, segundo a tipologia anterior, que há diferentes gradações no exercício da cidadania, e que essa tipologia não se resume a uma identidade única na qual todos, por tão somente pertencerem a um Estado-Nação, são iguais no que tange aos seus direitos. Cidadania é um processo que, segundo Nogueira (2001, p. 86),

[...] não avança de modo harmonioso e pacífico, mas sim através de recuos, saltos, irregularidades, e sempre em meio a fortíssimas tensões políticas e sociais. Eles variam de país para país e, no interior de cada país, atingem de modo desigual seus diversos grupos específicos.

Poderíamos afirmar, então, que a cidadania está sempre em contínuo processo de construção. É, nesse sentido, um conceito situacional, posto que corresponde a uma história que se faz com mudanças sociais, carregadas 
de lutas, dívidas com a modernidade, contradições e persistências na resolução dos candentes problemas sociais. Por fim, poderíamos também afirmar que a cidadania é uma identidade social política que está intrinsecamente vinculada a processos de exclusão-inclusão, que será o tema a ser analisado no próximo capítulo. 


\section{A DIALÉTICA DO CONCETTO DE EXCLUSÃO INCLUSÃOSOCAL}

Este capítulo está voltado a uma análise sobre o conceito Le inclusão e exclusão social e de como essas duas categorias estão intrinsecamente relacionadas. A importância da compreensão de ambas justifica-se ao afirmarmos que a inclusão social efetiva-se no combate às dimensões da exclusão. Isso quer dizer que, a priori, é necessário compreender o que causou a exclusão antes de criaremse estratégias de inclusão.

Segundo Scarcelli (2011, p. 30), inclusão “[...] refere-se ao ato ou efeito de incluir". No dicionário Aurélio (2010), o termo inclusão aparece como "abranger, compreender, conter, envolver, pôr ou estar dentro, inserir num ou fazer parte de um grupo". Associada ao adjetivo social "que diz respeito à sociedade", também segundo o dicionário, a inclusão social pode ser entendida como um ato de inserir algo na sociedade para que, assim, possa fazer parte dela. Esse conceito é extremamente vinculado ao seu oposto, a exclusão social, ou seja, para entender como funciona o processo de inclusão, faz-se necessário compreender como deu-se a exclusão. 
0 conceito de exclusão social é relativamente recente na literatura e teve como berço a Europa, na segunda metade do século XX (ZIONI, 2006). Lenoir (1989), em Les Exclus, publicado primeiramente em 1974, foi um marco para a compreensão do conceito vinculado ao sentido de inadaptação social. A exclusão é um fenômeno irredutivelmente social e sua origem a aproxima da compreensão de disfunção ${ }^{6}$ da própria sociedade. 0 autor chamou a atenção para o fato de que uma economia em expansão tende para a exclusão dos grupos que apresentam uma diferenciação física, psíquica e social.

De acordo com Escorel (2009), o processo de pauperização na França, na década de 1970, começou a atingir os grupos não considerados tradicionalmente marginalizados e que até então usufruíam dos benefícios do desenvolvimento econômico. "A exclusão social passou a ser usada para denominar o fenômeno integrante de uma 'nova questão social', problemática específica do final do século XX cujo núcleo duro foi identificado na crise do assalariamento como mecanismo de inserção social" (ESCOREL, 2009, p. 1).

Dupas (1998, p. 123) evidencia que

[...] a discussão sobre exclusão social apareceu na esteira do crescimento dos sem-teto e da pobreza urbana, da falta de perspectiva decorrente de desemprego de longo prazo, da falta de acesso a empregos e rendas por parte de minorias étnicas e imigrantes, da natureza crescentemente precária dos empregos disponíveis e da dificuldade que os jovens passaram a ter para ingressar no mercado de trabalho.

\footnotetext{
${ }^{6}$ Entende-se aqui por disfunção da sociedade o ato de divisão, dissociação, separação e segregação de membros desse grupo social.
} 
Segundo o autor, esse efeito foi, em parte, em decorrência do processo de globalização acentuado nos anos 1980.

Em consonância aos autores anteriores, Campos et al (2003) afirmam que a emergência de estudos sobre o conceito de exclusão social é consequência do agravamento dos processos excludentes da década de $1970 \mathrm{em}$ diante, nos países capitalistas, a partir da adoção de políticas macroeconômicas neoliberais e a emergência de inovações tecnológicas.

Segundo Escorel (2009), a noção de exclusão como o processo social progride a partir de trajetórias com rupturas de vínculos sociais frágeis. Dessa forma, a autora traça um paralelo entre a exclusão e a desvinculação, e deixa claro que esse fenômeno percorre diversos âmbitos sociais (o econômico, o familiar, o biológico, o cultural, o psicológico etc.). 0 conceito define processos sociais de discriminação, estigmatização e vulnerabilidade.

Para Wanderley (2001), a exclusão social é um processo de privação que inclui a pobreza, a discriminação, a subalternidade, a iniquidade e diversas formas de desigualdades. Em suma, a exclusão social não começa e termina apenas na pobreza, pois são múltiplos os fatores que corroboram para que ela aconteça.

Seguindo a linha de raciocínio de Escorel (2009) e de Wanderley (2001), Déchamps (1998 apud ESTIVILL, 2003, p. 47, grifo do autor) mostra-nos a existência de três dimensões da exclusão social - a econômica, a social e a simbólica.

[...] a dimensão econômica da exclusão implica a sucessiva ausência do mundo produtivo e do consumo, a sua dimensão social compreende a perda da sociabilidade primária e secundária, e a sua 
dimensão simbólica é definida pelos comportamentos e valores comuns, assim como pelas representações que tendem a classificar socialmente as pessoas (dé-chéance, incompetência, mediocridade, identidade negativa).

O exemplo da pobreza, utilizado por Sposati (1999), ratifica as dimensões citadas por Déchamps (1998 apud ESTIVILL, 2003). A pobreza absoluta ou relativa (uma questão econômica) pode ser somada a questões de discriminação e estigma, seja pela condição econômica, de gênero, raça, orientação sexual etc. À exclusão social, nesse caso, soma-se a privação econômica, a discriminação e a fragilidade dos vínculos sociais.

Afirma Kowarick (2003) que há uma imprecisão no termo exclusão e que ele é usado de forma ampla e escorregadia, sendo, algumas vezes, confundido com vulnerabilidade. Segundo o autor, o termo exclusão traz a ideia de não ser admitido ou mesmo de ser repelido, expulso e banido de um dado grupo. Ele aproxima o conceito à ideia de destituição de direitos ou de perda do direito de ter direitos.

Em suma, exclusão aponta uma condição de desposessão de direitos, chegando a atingir casos extremos de extermínio em massa, cujos exemplos podem ser encontrados entre os considerados heréticos pela Santa Inquisição, os judeus e ciganos na Alemanha nazista ou, mais recentemente, as vítimas da atrocidade em Kosovo. (KOWARICK, 2003, p. 22).

Resumindo, para o autor, exclusão quer dizer banimento e/ou isolamento, o que difere do que comumente 
chamam de vulnerabilidade. Indivíduos vulneráveis têm vínculos sociais e econômicos precários.

Castel (1994; 2000), por sua vez, não utiliza o conceito de exclusão por considerá-lo atualmente um conceito mala, ou seja, é tão amplo que deixa de evidenciar os diferentes processos que atravessam a sociedade contemporânea. 0 autor propõe o uso do conceito de desfiliação para referir-se a um alto grau de vulnerabilidade social. Para o autor, não se pode considerar que exclusão seja uma condição de ausência de algo (seja de renda, alimento, moradia, educação, saúde etc.), mas, sim, a composição de três eixos: precarização do trabalho, precarização da sociabilidade primária ${ }^{7}$ e negação do status social. A relação entre os eixos cria quatro estados entre a integração e a desfiliação:

[...] zona de integração (trabalho estável e forte inserção relacional, que sempre estão juntos), a zona de vulnerabilidade (trabalho precário e fragilidade dos apoios relacionais) e a zona de marginalidade, que prefiro chamar de zona de desfiliação para marcar nitidamente a amplitude do duplo processo de desligamento: ausência de trabalho e isolamento relacional [...] tratamento dispensado à indigência inválida define uma quarta zona, a zona da assistência. (CASTEL, 1997, p. 23-24, grifo do autor).

\footnotetext{
7 O sistema de proteção social para Castel (1998a) é composto de dois modelos: sociabilidade primária e sociabilidade secundária. A primária é regida pelos vínculos estabelecidos na relação de proximidade e pertencimento, ou seja, uma rede sem a mediação de uma instituição específica. Dentre eles, encontram-se a família, a vizinhança, os amigos etc. A secundária emerge com a fragilidade da primária, quando a sociedade torna-se mais complexa e ocorre um entrelaçamento das redes que compõem a primeira. Nela, torna-se necessário um atendimento mais sofisticado e institucional. É nesse momento que emerge a proteção social institucionalizada.
} 
Como é possível perceber, Castel (1997, p.31) deixa claro que os pontos centrais para a desfiliação são o trabalho e as relações sociais. Desfiliação, assim, segundo o autor, pode ser compreendida pela "[...] conjunção perda de trabalho-isolamento relacional".

Em relação ao trabalho, o autor analisa esse eixo segundo a queda da sociedade salarial ${ }^{8}$. Em seu texto As metamorfoses da questão social, o autor evidencia não só a precarização do trabalho e a perda das garantias trabalhistas na sociedade contemporânea, mas também como esse processo provoca um estado de vulnerabilidade social.

No que se refere à rede de sociabilidade primária, Castel (1994) considera-a como sendo a de uma rede de relações sociais, responsável pelo suporte e solidariedade (família, amigos, vizinhos, colegas de trabalho etc.) que não se fundamenta nas instituições formais do Estado. Essa rede pode ser compreendida como uma rede de laços entre os membros que a compõem e que nela criam sentimentos de pertencimento. Em meio a esse grupo, são reproduzidos costumes e tradições, os papéis sociais são veiculados e, assim, uma existência social é reproduzida internamente. Em suma, as relações sociais são um elemento constitutivo do que o autor denomina de proteção

\footnotetext{
8 O modelo de sociedade característico no século XX é construído ao redor do trabalho e é denominado por Castel (1998) como a sociedade salarial industrial. Tal sociedade é caracterizada por sua organização em torno de uma economia de mercado, que compra e vende trabalho-mercadoria, regulada por um direito do trabalho que estabelece as relações laborais entre o capital e o trabalho e que tem em seu bojo um Estado de bem-estar social construído no ideal da democracia burguesa. Para Castel (1998), as legislações trabalhistas e políticas sociais que instituíram a seguridade social (direito à aposentadoria, seguro desemprego e assistência à saúde) são as materializações dos suportes sociais garantidos por instituições do Estado nas quais se estruturaram as relações de trabalho na sociedade salarial.
} 
aproximada. Entretanto, o estado de desfiliação para Castel (1998a) é formado pela perda do trabalho e da sociabilidade primária, porque tais perdas acarretam a privação econômica e a fragilidade de laços sociais.

Além desses dois quesitos, para Castel (1998a; 1998b), pode ocorrer o processo de desfiliação, quando há a negação das normas estabelecidas pela sociedade e, assim, a ruptura com o status ou a posição de um indivíduo pertencente a esse grupo. 0 autor utiliza a história de Tristão e Isolda (CASTEL, 1998b) para exemplificar essa questão. São os casos de indivíduos desfiliados pela negação das normas impostas ou mesmo pela falta de oportunidade de acesso a elas, tendo, assim, o seu pertencimento negado.

No Brasil, o conceito de exclusão social nas ciências humanas aparece quase sempre relacionado à desigualdade de renda. A exclusão social configura-se como marca inquestionável do desenvolvimento capitalista no país. Véras (2001) ressalta que os processos sociais excludentes estão presentes desde os tempos coloniais (população indígena e negra), contudo, tornaram-se mais intensos durante o período militar. Para a autora, a exclusão é a consequência do desejo da burguesia de subordinar o social ao econômico. 0 resultado é o controle dos dominados por meio da lógica de poder dominantes-dominados.

Campos et al (2003) aponta a existência de duas formas de desigualdade no país: a velha e a nova exclusão social. A velha exclusão manifesta-se devido aos baixos níveis de escolaridade, à falta de acesso a bens e serviços básicos, ao trato com as diferenças raciais e étnicas etc. Considerando-se as transformações que ocorreram nos países emergentes, principalmente a partir da segunda metade do século XX, novas formas de exclusão surgem 
sem que a primeira tenha sido superada completamente. Para o autor, no Brasil, as novas formas de exclusão, que convivem com as velhas, podem ser identificadas no número de moradores em situação de rua, na precarização do mundo do trabalho, no baixo nível de renda, no advento da insegurança vivenciada nas diversas formas de violência etc.

Embora diversos indicadores sociais - como índice de analfabetismo, renda, acesso à saúde pública, saneamento e moradia - indiquem que a velha exclusão social no Brasil tenha melhorado desde os anos 1980, ela não foi superada. É preciso verificar que o processo de individualização e o consumo, dentre outros fatores, acirram o processo da nova exclusão social.

Véras (2001) afirma que as condições desfavoráveis de tais contingentes excluídos contribuíram para gerar sentimento de hostilidade, desconfiança e medo por parte dos demais segmentos, fazendo com que aumentasse a demanda por políticas de segurança e repressão, agravando ainda mais o processo de exclusão. Ademais, a autora cita a proliferação de loteamentos fechados, condomínios horizontais (prédios), shopping centers com câmeras de vigilâncias, seguranças nas portas e controle de acesso como consequências desse processo e formas de segregação.

No campo da saúde, a Organização Internacional do Trabalho (OIT) e a Organização Pan-Americana da Saúde (OPS) definem a exclusão social como um processo multidimensional que abarca a ausência tanto de recursos, quanto de oportunidades e de pertencimento. Como já apontado, por pertencimento entende-se a construção de laços sociais que permite aos indivíduos fazer parte de uma rede social (OIT, OPS, 1999). 
É possível perceber, portanto, por meio da definição de exclusão social dos autores mencionados anteriormente, que esse conceito é multidimensional, ou seja, engloba várias questões. Segundo Sawaia (2001), esse é um conceito que permite usar diversos repertórios, desde a concepção de desigualdade, como sendo resultante de uma deficiência ou inadaptação individual, à falta de algo, até mesmo como condição de uma injustiça social. De acordo com a autora, a sociedade exclui para incluir. Essa é uma dialética da própria sociedade.

A sociedade exclui para incluir e essa transmutação é condição da ordem social desigual, o que implica o caráter ilusório da inclusão. Todos estamos inseridos de algum modo, nem sempre digno, no circuito reprodutivo das atividades econômicas, sendo a grande maioria da humanidade inserida através da insuficiência e das privações, que se desdobram para fora do econômico. (SAWAIA, 2001, p. 8).

Para a autora, essa dialética dos processos de inclusão e exclusão não é uma falha do capitalismo, mas, sim, um processo intrínseco da sua lógica, que se manifesta nas contradições da desigualdade e da necessidade de uma legitimação social. A dialética inclusão/exclusão demonstra que essa noção deve ser compreendida tanto como um processo que pode estar em constante movimento - o indivíduo/grupo pode estar excluído em um fator e incluído em outro -, quanto estando relacionada com os modos de sociabilidade e valores sociais (SAWAIA, 2001).

Nesse contexto, a inclusão é parte constitutiva da exclusão, isto é, não é uma coisa ou um estado, mas, sim, um processo que envolve o indivíduo perante a sociedade. 
É um produto do funcionamento do sistema (SAWAIA, 2001). Seus mecanismos estão inseridos nas estratégicas histórias de manutenção de uma ordem social perversa, no estabelecimento de formas de desigualdade, nos processos de concentração de riqueza. 0 excluído é parte integrante de uma sociedade, de forma a sustentar uma dada ordem social.

\section{O CONCEITO DE EXCLUSÃOSOCCAL}

Nossa definição se aproximará de alguns pressupostos apresentados por Escorel (2009), Wanderley (2001) e Castel (1998a), ao afirmarmos que a exclusão é um estado de vulnerabilidade em níveis de maior ou menor intensidade e que percorre de diversos âmbitos sociais: o econômico, o social, o biológico e o psicológico. A exclusão social não se esgota na desigualdade social, pois são múltiplos os fatores que corroboram para que ela aconteça. Assim, a exclusão pode e deve ser compreendida como um processo pluridimensional que segrega e inferioriza um indivíduo ou um grupo perante sua comunidade e seu território. Sua base de segregação está nos valores dominantes da sociedade.

Para nossa definição, utilizaremos três dimensões que consideramos ser os pilares desencadeadores do processo de exclusão social. Para tal, emprestaremos dois eixos apresentados por Castel (1998a): precarização do trabalho e precarização da sociabilidade primária. Acrescentaremos mais um eixo, o do estigma. Em suma, partimos da definição da exclusão social como processo de vulnerabilidade composto de três dimensões: 
precarização do trabalho, precarização da sociabilidade primária e estigma.

\section{a) Precarização do trabalho}

Bauman (2001), Beck (2011) e Castel (1998a) evidenciam a centralidade do trabalho como meio para a inserção social do indivíduo na modernidade. Outros autores, como Clavel (2012), em consonância a Bauman (2001), ao analisar a exclusão social, também consideram que o trabalho é parte constitutiva da construção de uma identidade coletiva e individual. Clavel (2012) afirma que a ausência do trabalho pode produzir a perda do sentimento de pertencimento a um grupo, a uma classe, a um sindicato.

Paugam (2006) sinaliza que a ausência de estabilidade no emprego gera no indivíduo sentimentos de culpa e de falta de perspectiva de vida pela perda de sua identidade de trabalhador. 0 autor enfatiza também os sentimentos de vergonha e apatia dos desempregados de longo período, fazendo com que se afastem do convívio social com os amigos e mesmo com os familiares. Chama ainda a atenção para a atual instabilidade no mercado de trabalho, que gera formas de contratação precárias e acentua a rejeição dos trabalhadores menos qualificados.

É evidente a importância da dimensão do trabalho no que se refere à inclusão do indivíduo na sociedade. Entretanto, cabe aqui fazer uma reflexão sobre os impactos das transformações que a categoria trabalho tem sofrido na sociedade contemporânea.

Ao examinar as transformações no mundo do trabalho ante a internacionalização do mercado decorrente 
da globalização na sociedade contemporânea, Castel (1998a) identifica a ocorrência de dois tipos de redução de custos em face dos requisitos da flexibilização: minimização do preço da força de trabalho e maximização de sua eficácia produtiva. Tais processos produzem o desemprego, a precarização e a individualização dos comportamentos no trabalho. A precarização decorre do desenvolvimento tecnológico da evolução do capitalismo, e a flexibilização, por sua vez, provoca a individualização dos comportamentos no trabalho.

Tanto Bauman (2001) quanto Beck (2011) estão alinhados à análise de Castel (1998a), ao partirem da certeza sobre o fim do emprego industrial no cerne das características da sociedade moderna. Beck (2011) analisa a questão do trabalho a partir da noção da sociedade de risco. 0 autor ressalta que, quanto mais as relações, as condições e o mercado são desregulamentados e flexibilizados, mais rapidamente, e com eficiência, a sociedade do trabalho torna-se sociedade de risco.

É no contexto da individualização contemporânea que Beck (2011) analisa a despadronização do trabalho assalariado, da formação e da ocupação, afirmando que o trabalho flexível e a subocupação substituem a ocupação integral. 0 direito, o local e o tempo que eram os pilares desse mundo do trabalho tradicional não são mais considerados como tal. Para o autor, nesse contexto de incerteza, os riscos psíquicos e de saúde são privatizados para o próprio trabalhador, sendo assim, cada trabalhador é responsabilizado individualmente. 0 indivíduo deve autogerir-se, inclusive, em aspectos relativos à proteção social e às condições de trabalho. A grande característica do trabalhador contemporâneo é o fato de constituir-se em 
uma espécie de multiuso, de modo que sua existência é marcada pela insegurança constante.

Assim como em Beck (2011), para Bauman (2001), os trabalhadores, passam a conviver com a incerteza do trabalho flexível e sem a possibilidade vitalícia de trabalho, que foram extintas junto com as certezas do trabalho na era do capitalismo industrial. Considera Bauman (2001) que a incerteza sempre acompanhou o trabalhador, mesmo na fase anterior da sociedade, mas na sociedade contemporânea adquire o caráter de poderosa força individualizadora que, ao contrário de unir, divide. Indica também que, na atualidade, ocorre a perda da capacidade de coesão, historicamente atribuída ao trabalho, e da construção da identidade, a partir de classes sociais coesas. 0 trabalho de longa duração, aqui, é também substituído pela volatilidade do mercado da força de trabalho.

Segundo Bauman (2001), a reestruturação produtiva e industrial na sociedade contemporânea decorre de um processo que compatibiliza mudanças organizacionais, redefinições de papéis dos Estados nacionais, centralidade do capital financeiro, tecnologias informatizadas e a crescente necessidade de garantia do lucro. Esse novo modelo rompe com o do fordismo e tem por base a flexibilização do trabalho e a necessidade de um trabalhador polivalente, que seja capaz de lidar com as mais diversas tecnologias, de estar disponível 24 horas, de aprender novas formas de gestão que enfocam a subjetividade, de não ser mais um empregado, mas, sim, um colaborador, de redefinir a relação de solidariedade operária por meio da individualização do salário e as relações entre pares por clientes. 0 trabalhador deve ser um indivíduo 
empreendedor, estar sempre capacitado e ser responsabilizado por suas escolhas e sua carreira.

Castells (1999b), em conformidade com os autores anteriores, afirma que, com o advento do fim da sociedade industrial, surge um novo sistema de produção. Ademais, declara que, nesse novo sistema, a produtividade e a competitividade constituem os seus principais processos, nos quais a primeira origina-se da inovação e a segunda da flexibilização.

Portanto, empresas, regiões, países, unidades econômicas de todas as espécies preparam suas relações de produção para maximizar a inovação e a flexibilidade. A tecnologia da informação e a capacidade cultural de utilizá-la são fundamentais no desempenho da nova função da produção. Além disso, um novo tipo de organização e administração, com vistas à adaptabilidade e coordenação simultâneas, tornam-se a base do sistema operacional mais efetivo, exemplificado pelo que rotulei de empresa em rede. (CASTELLS, 1999b, p. 417).

Nesse novo contexto, a mão de obra é redefinida, emergindo daí dois tipos de trabalhadores denominados pelo autor como mão de obra genérica e mão de obra autoprogramável. As características primordiais que diferenciam os dois trabalhadores são a capacidade educacional e a incorporação de informação. Essas características, empregadas à mão de obra autoprogramável, permitem ao trabalhador a "[...] capacidade para uma redefinição constante das especialidades necessárias à determinada tarefa [...]" (idem). Em contrapartida, a mão de obra genérica, sem acesso à educação, "[...] recebe determinada tarefa sem nenhum recurso de reprogramação, e não se 
pressupõe a incorporação de informação e conhecimentos além da capacidade de receber e executar sinais [...]" (idem). Dessa maneira, os trabalhadores podem e são facilmente substituídos por máquinas ou outros trabalhadores com custos mais baixos.

Embora, no conjunto, sejam imprescindíveis, ao processo produtivo, individualmente esses trabalhadores são dispensáveis, pois o valor agregado de cada um deles representa uma pequena fração do que é gerado pela e para a organização. Máquinas e mão-de-obra genérica de várias origens e locais coabitam os mesmos circuitos subservientes do sistema de produção. (ibidem, p. 418).

Frente a um mundo globalizado, tecnológico, rápido, informacional e individualizado, o trabalhador vê-se imerso na necessidade, cada vez maior, de qualificar-se, reinventar-se e atualizar-se. Logicamente, um sem número desses trabalhadores não consegue acompanhar a nova necessidade do mercado. Frente ao processo de individualização radicalizada, a culpa recai sobre o próprio trabalhador que "[...] não consegue acompanhar a constante e necessária atualização profissional. Com isso, ficam para trás na rodada de 'enxugamento' dessa camada intermediária, que constituiu a força das sociedades capitalistas avançadas durante a era industrial e agora se encolhe cada vez mais" (CASTELLS, 1999b, p. 421).

Segundo Castells (1999b), os trabalhadores genéricos são levados a circular por vários empregos, na maioria das vezes informais, sem vínculos e inseguros. Essa instabilidade dificulta ainda mais o acesso à educação, fazendo com que o trabalhador entre num ciclo que não mais consegue sair. 
A perda da relação estável a um nível mais alto de incidência de crises profundas na vida familiar: perda temporária de emprego, crises pessoais, doenças, vícios em drogas/álcool, perda da empregabilidade, perda de bens, perda de crédito. Muitas dessas crises ligam-se entre si, provocando a espiral descendente da exclusão social rumo ao que chamei de 'os buracos negros do capitalismo informacional'. (CASTELLS, 1999b, p. 421).

Esse novo contexto do mercado de trabalho contemporâneo radicaliza ainda mais a desigualdade social existente, privilegiando, obviamente, quem tem a possibilidade de qualificar-se de forma constante. E é ainda mais perverso ao responsabilizar o indivíduo por sua dificuldade de inserção ao trabalho (BAUMAN, 2001; BECK, 2011).

A despeito disso, ressaltam-se os dois aspectos dessa situação: da parte do trabalhador, a precarização das relações de trabalho, que gera desemprego, terceirização, subcontratação etc.; do lado do empregador, o resultado manifesta-se em lucro e acumulação.

Os maiores consensos entre os quatro autores Castells (1999b), Bauman (2001), Beck (2011) e Castel (1998a) - estão na evidente precarização do mundo do trabalho contemporâneo, na preocupação com a responsabilização do indivíduo e de como cada um deve aprender a conviver com suas ansiedades e preocupações de forma isolada.

Em suma, o trabalho contemporâneo caracteriza-se majoritariamente por contratos não regulamentados, por tempo parcial, pelo emprego por tempo determinado, pela subcontratação, pelas chamadas economias informais que englobam o trabalho autônomo. Essa é mais uma das características do processo de individualização refletida 
agora no mundo do trabalho. Seu produto é o aumento da precarização das relações de trabalho, o que não significa que na sociedade atual o trabalho perca sua centralidade. Ao contrário, ele se mantém como um dos vetores importantes na organização da sociedade, nas relações sociais entre indivíduos e grupo, mas reconfigura-se de acordo com as características atuais (BAUMAN, 2001; CASTEL, 1998; CASTELLS, 1999).

Isso quer dizer que o trabalho tem sua importância enfraquecida na construção da identidade individual e coletiva (quando falamos de classe), privatiza os riscos e traz um sentimento ainda maior de incerteza e responsabilização individual. No lugar da proteção assegurada pelo trabalho, prevalece, hoje, o discurso liberal do empreendedorismo, que direciona com mais força a ideia de responsabilização do indivíduo sobre seu destino e êxito em sua vida profissional. 0 processo de individualização fragiliza os vínculos e suportes de proteção do trabalhador (BECK, 2011). Tais transformações impactam negativamente na forma com que essa categoria contribui para a inserção social dos indivíduos na sociedade contemporânea.

\section{b) Precarização da sociabilidade primária}

A sociabilidade primária para Castel (1998a) é regida pelos vínculos estabelecidos na relação de proximidade, pertencimento e interdependência, ou seja, uma rede sem a mediação de uma instituição - Estado e políticas públicas. São os vínculos com a família, vizinhança, amigos etc. São essas as relações que garantem o suporte social necessário para o indivíduo sentir-se parte integrante da sociedade. Partiremos dessa definição. 
Na sociedade moderna, os laços sociais mais fortes estavam centrados na família e na classe social; em suma, laços comunitários, um por sangue e outro pelo sentimento de pertencimento a um grupo (e.g. burguesia/proletariado). Esses dois pilares eram constitutivos da inserção social, na construção da identidade e no suporte social do indivíduo no mundo moderno. Uma das consequências para o processo de desfiliação, segundo Castel (1998a), é a perda dos suportes sociais. Como já analisado no primeiro capítulo, os processos de individualização e de consumo influenciaram e flexibilizaram tais pilares, de forma que alteraram significativamente os modos de sociabilidade e a criação de laços sociais na sociedade contemporânea. Os impactos que se pretende analisar aqui são: a fragilidade dos laços comunitários e as transformações na categoria família.

Lipovetsky (2005a) afirma que, a partir de um processo narcísico, no qual o eu torna-se o objeto de investimento e o indivíduo vê-se na busca constante pela realização do seu ego, os laços sociais tornam-se cada vez mais frágeis na sociedade contemporânea. Consoante esse autor, para Castel (1998a), o processo de individualização faz com que o indivíduo feche-se e esteja voltado para si mesmo. Tal como Lipovetsky (2005a), ele também lança mão da lenda de Narciso para constatar que, ao voltar-se para dentro de si, o indivíduo tende a confundir-se com sua própria imagem.

Sob essa mesma perspectiva, Bauman (2004) demonstra que a fragilidade dos laços humanos na sociedade contemporânea está carregada de sentimentos de insegurança. Isso faz com que os indivíduos relacionem-se, mutuamente, com desconfiança e temeridade quanto ao estreitamento e prolongamento de vínculos. 0 que de fato 
ocorre é que, devido ao medo de assumir responsabilidades por parcerias mais prolongadas, tais relações são percebidas como ameaças à individualidade.

Nesse cenário, e com o surgimento da internet 2.0, emergem as relações virtuais que se caracterizam pela virtualidade, sendo consideradas mais superficiais no sentido do pressuposto de que são interações frágeis, que não promovem contato físico e dificultam a intimidade. Tais relações, segundo Bauman (2004), promovem a ilusão da criação de laços afetivos, mas elas podem ser desfeitas com a mesma rapidez com que foram construídas.

Bauman (2001, p. 114) aponta o surgimento de uma nova categoria de sociabilidade contemporânea, a que é utilizada nos "[...] espaços públicos, mas não civis". Para o autor, há um esvaziamento do espaço público e, consequentemente, um rebaixamento da integração política, na qual as preocupações e as motivações sociais estão limitadas aos interesses individuais e privados. Em suma, se há uma interação nos espaços públicos, essa dificilmente se dá por uma questão coletiva ou cívica.

É nesse sentido que, para o autor, há na atualidade um aniquilamento do conceito de coisa pública, porque a individualização produzida na contemporaneidade neoliberal leva o sujeito a não ver qualquer sentido na sociedade da qual faz parte. No dizer de Castel (1998a), isso é percebido pela falta da recusa em não se engajar por medo de assumir responsabilidades e de construir laços sociais mais duradouros.

Ainda citando Bauman (2004), ele faz uma crítica ao mercado que se apropria de ideias e sentimentos com o intuito de estimular o consumo. 0 autor enfatiza a apropriação dos laços humanos pelo mercado, que os transforma 
em mercadorias a serem vendidas em suas prateleiras, como qualquer outro produto.

Segundo o autor, o mercado procura transformar os laços humanos em produtos postos à venda, tornando-os objetos que podem ser comprados.

Onde há chance de lucro - e os especialistas em marketing levam sua engenhosidade ao limite para indicar maneiras de adquirir em lojas a solidariedade, o sorriso amigo, o convívio ou a ajuda no momento de necessidade. [...] Em versão à venda, os vínculos se transformam em mercadorias, ou seja, são transformados para outro domínio, governados pelo mercado, e deixam de ser os tipos de vínculos capazes de satisfazer a necessidade de convívio e que só nesta podem ser concebidos e mantidos vivos. (BAUMAN, 2004, p. 91).

Ao transformar seres humanos e relacionamentos em produtos de consumo, os agenciadores capitalistas proporcionam a ampliação da precarização dos laços sociais, transformando-os segundo a lógica de mercado, que impõe uma velocidade cada vez maior no uso dos objetos e no seu descarte - imperativo da substituição frenética dos modelos mais novos disponíveis. Os laços humanos passam, então, a adquirir essa mesma característica, a de objetos descartáveis.

O desvanecimento das habilidades de solidariedade é reforçado e acelerado pela tendência, inspirada no estilo de vida consumista, a tratar os outros seres humanos como objeto de consumo e julgá-los segundo o padrão desses objetos, pelo volume de prazer que provavelmente oferecem e em termos de seu 'valor monetário' [...] A solidariedade humana é a primeira baixa causada pelo triunfo do mercado consumidor. (BAUMAN, 2004, p. 96). 
As relações humanas sofrem, assim, uma mutação, transformando-se em objetos de consumo e, nessa nova condição, assumem novos atributos: utilidade, descartabilidade, durabilidade. 0 relacionamento social converte-se em uma espécie de troca, ou seja, os sujeitos tomam atitudes a partir do que receberam ou com base no que receberão e esquecem-se dos vínculos de solidariedade e amizade, transformando os laços afetivos em uma questão de interesse e troca. É a busca por gratificação instantânea e felicidade individual. Os indivíduos ficam imersos nas fantasias do consumo hedonista, não se preocupando com nada mais além do prazer momentâneo.

Em meio a esse cenário, a família, tal como ela se consolida na modernidade, também sofre transformações. Castells (2000) afirma que o modelo familiar patriarcal entrou em crise e, consequentemente, houve o crescimento de famílias chefiadas por mulheres, bem como a de outras configurações familiares diferentes do modelo patriarcal. É nesse sentido que Perucchi e Beirão (2007, p. 66) analisam: "O modelo patriarcal de família, caracterizado pelo arranjo composto por pai, mãe e filhos que convivem sob a égide da autoridade do primeiro sobre os demais, está em crise". Tal crise vem em decorrência das lutas históricas de emancipação feminina e de conscientização da mulher em um contexto de transformação no mercado de trabalho.

As transformações da categoria família são movidas por vários processos que estão vinculados, dentre eles: 0 processo de individualização - já apresentado -, a emancipação da mulher no mercado de trabalho, o envelhecimento da população, a diminuição da taxa de natalidade e novos formatos familiares. É importante ressaltar que o processo de individualização está intimamente vinculado 
aos demais, ou melhor, ele é uma das causas dos demais processos.

Relativamente à emancipação da mulher no mercado de trabalho, segundo Silva et. al. (2005), nos últimos 50 anos, houve um crescimento da participação feminina. Tal fenômeno é explicado por uma combinação de fatores: o avanço da industrialização, o processo de urbanização e a queda das taxas de fecundidade. Para o entendimento das alterações familiares das últimas décadas, sem dúvida, o acesso da mulher ao mercado de trabalho exerce um papel primordial. Em decorrência disso, a estrutura familiar sofre as seguintes consequências: seu tamanho (pelo comportamento da fecundidade), sua hierarquia interna (uma maior presença da mulher como provedora), e a tendência à desintegração dos laços familiares (mais autonomia da mulher).

0 aumento da esperança de vida ao nascer combinado à queda do nível geral de fecundidade resultam no aumento da população idosa. 0 envelhecimento populacional é, hoje, um fenômeno mundial resultante, além da queda do número de filhos, da redução da mortalidade nas idades avançadas. A longevidade tem proporcionado a convivência intergeracional, encontrando-se até quatro gerações em uma mesma residência. Em contrapartida, esse fenômeno também tem trazido à tona a condição de muitos idosos sem o suporte familiar e em condição de vulnerabilidade social.

Para Villa (2012), recentemente, as famílias são formadas por diversas estruturas: casais que já tiveram outros casamentos, pessoas que vivem só, pais com filhos adotivos, mães solteiras com seus filhos, casais que não possuem filhos, uniões homoafetivas, avós com netos, 
famílias expandidas, dentre outras. De acordo com a autora, os valores tradicionais associados à família, apoiados no princípio que atrelava a fatores como sexualidade, reprodução, casamento e manutenção da herança, passaram gradativamente a ser transformados na sociedade contemporânea. Não cabe mais denominar família apenas por aquela formada a partir do casamento entre homem e mulher.

Em suma, diante desse cenário, verifica-se que os processos apresentados transformaram a conformação e a manutenção dos laços sociais primários na sociedade contemporânea. De certa maneira, é possível afirmar que, hoje, sob a perspectiva de Bauman (2001; 2004), Castel (1998a) e Lipovetsky (2005a), esses laços estão mais frágeis, o que gera maior sentimento de insegurança nos indivíduos contemporâneos.

\section{c) Estigma}

Para essa definição, utilizaremos os conceitos emitidos pelo sociólogo Goffman (1978, p. 11), que faz referência ao uso da palavra estigma pelos gregos, definida como "[...] sinais corporais com os quais se procurava evidenciar alguma coisa de extraordinário ou mau sobre o status moral de quem a apresentava”. Segundo o autor, “[...] a sociedade estabelece os meios de categorizar os indivíduos e os atributos considerados comuns, aceitáveis e naturais dentro de cada uma dessas categorias" (ibidem, p. 12). Criam-se categorias e grupos aos quais cada um pertence e, assim, formam-se as identidades sociais.

Segundo Goffman (1978), o estigma é um atributo menos desejável que torna um indivíduo diferente, de 
maneira que os ditos normais deixam de considerá-lo criatura comum, reduzindo-o a uma pessoa estragada e diminuída. Tal característica é um estigma, especialmente quando o seu efeito de descrédito é muito grande algumas vezes, ele também é considerado um defeito, uma fraqueza, uma desvantagem - e constitui uma discrepância específica entre a identidade social virtual e a identidade social real. Sendo assim, a identidade real é o conjunto de atributos que uma pessoa prova ter, em contrapartida, a identidade virtual é o conjunto de atributos impostos pelos ditos normais a tal pessoa; é um estereótipo. Este último, portanto, embutirá um descrédito, formando o que o autor chamou de identidade social deteriorada. "O termo estigma, portanto, será usado em referência a um atributo profundamente depreciativo [...]" (GOFFMAN, 1978, p. 13).

Goffman (1978) afirma que o estigma pode ocorrer devido a três circunstâncias: abominações do corpo, como as diversas deformidades físicas; culpa de caráter individual, como vaidade, desonestidade; e estigmas de raças, tribos, nação e religião. 0 sujeito estigmatizado tem sua capacidade de ação delimitada pela sociedade, que indica o quanto de perigoso pode ele representar socialmente. 0 autor diz que a intensidade de visibilização das marcas do indivíduo estigmatizado dá o grau de dificuldades de reversão de sua imagem projetada e diferenciada pelos padrões aceitos de comportamento social.

Em suma, o estigma é uma construção social que delimita categorias e estereótipos considerados padrões, segundo as normas sociais vigentes. 0 estigma dificulta a formação de laços sociais e o acesso ao mercado de trabalho, provocando o isolamento. 


\section{TIPOLOGA DA EXCLUSÃO SOCAAL}

Explicitados os eixos que compõem a categoria exclusão social, cabe afirmar que é a presença dos três eixos, em conjunto, que ratifica o processo de exclusão social. A presença de um ou de dois evidencia graus de vulnerabilidade. 0 que não é menos importante, pois a presença desses pode levar à inserção em outros eixos e, assim, à exclusão. Dessa maneira, afirmamos aqui existirem três tipos de indivíduos em vulnerabilidade e um excluído.

0 primeiro indivíduo em vulnerabilidade, que chamaremos de economicamente inativo, está inserido na dimensão de precarização do trabalho. Trata-se das pessoas que estão permanentemente ou temporariamente excluídas do mercado de trabalho e sem alguma fonte de renda, direta ou indiretamente. Essa dimensão as impossibilita, em consequência, ao acesso ao consumo, que é, como vimos no primeiro capítulo deste livro, um dos elementos primordiais da sociedade contemporânea. Segundo Bauman (2001) e Lipovetsky (2005a), a inclusão na sociedade contemporânea ocorre através do consumo, o que, na realidade, não se caracteriza por uma verdadeira inclusão, mas dá, sim, uma falsa sensação de ser parte dessa sociedade por meio da possibilidade de adquirir um objeto de consumo, construindo, assim, sua identidade social e aproximando-se dos que também possuem o mesmo objeto.

O segundo indivíduo em vulnerabilidade, o solitário, está inserido na dimensão da precarização da sociabilidade primária. Trata-se dos que não possuem suporte social e relações que o façam sentir-se parte integrante de 
um grupo. Frente ao processo de individualização, essa dimensão está cada vez mais presente na sociedade contemporânea. Tal fenômeno faz com que cada vez mais sejam necessárias políticas públicas que supram essa dimensão com a assistência do Estado.

0 terceiro indivíduo em vulnerabilidade é o estereotipado, que está inserido na dimensão do estigma. Trata-se dos que possuem alguma característica indesejada socialmente. São indivíduos rotulados, que sofrem preconceitos e, portanto, sofrem para serem aceitos na sociedade. Para alguns casos, há políticas de inclusão, como nos casos dos negros, índios, deficientes, sujeitos em sofrimento psíquico, dentre outros. Entretanto, mesmo com políticas públicas a eles dirigidas, sem a alteração do imaginário social, eles não conseguem, de fato, ser efetivamente aceitos.

Conforme já exposto, um indivíduo pode possuir mais de uma dessas dimensões, o que agravaria o seu grau de vulnerabilidade. Entretanto, se possuir as três, ele se encaixaria no que denominamos de excluído. Aqui, encaixam-se os indivíduos em situação de rua, idosos abandonados nos asilos, moradores dos hospitais psiquiátricos, dentre outros. São os indivíduos em grau extremos de vulnerabilidade.

Por fim, pode-se afirmar que são múltiplas as causas que levam um indivíduo à vulnerabilidade social e, em casos mais graves, à sua exclusão social.

Conclui-se, assim, que a inclusão social é uma ação política pela qual uma instituição, que pode ser pública (Estado), organização da sociedade civil e privada, visa alterar um dado estado de exclusão social. Se ela visa alterar a exclusão - que é composta de três dimensões 
desencadeadoras (precarização do trabalho, precarização da sociabilidade primária e estigma) -, temos como pressuposto que essa ação deve, então, atacar essas causas para, assim, pôr fim ao estado de exclusão desse sujeito ou grupo excluído.

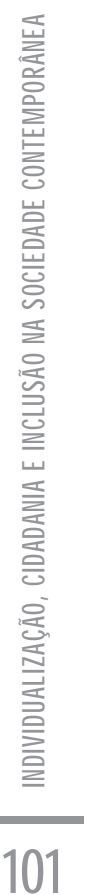




\section{REIICÊNCIAS...}

este livro, analisamos três conceitos fundamentais para as ciências sociais e centrais para a compreensão dos processos sociais contemporâneos, que são a individualização, a cidadania e a exclusão/inclusão social.

0 primeiro conceito trata de um processo iniciado com o advento da modernidade, da razão e do avanço do capitalismo, que fez emergir a noção de indivíduo. Entretanto, frente a um ideal de sociedade, esse indivíduo esteve preso às amarras das instituições que compunham a organização social: a família, o trabalho, a noção de gênero, o Estado etc. Com as transformações da sociedade contemporânea, que se tornaram mais evidentes a partir da segunda metade do século XX em diante, esse indivíduo libertou-se de tais amarras e, assim, radicalizou-se. A valorização da noção de igualdade na modernidade cedeu lugar à diferenciação, à liberdade de construção da identidade e à sobreposição do individual sobre o coletivo. Entretanto, se o processo de individualização liberta o indivíduo das amarras da modernidade, em contrapartida, insere-o em novas amarras, como a do consumo, da necessidade de construção de identidades, da responsabilidade por sua biografia e de novas contradições que ainda precisamos decifrar.

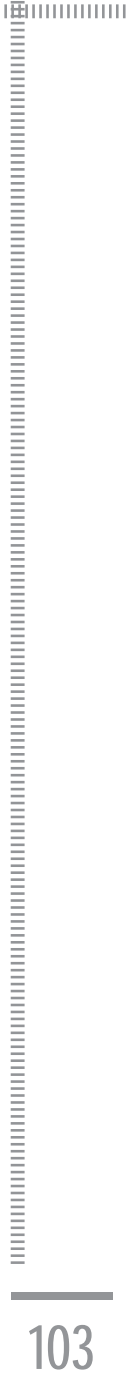


São tais transformações que impactam as relações entre a sociedade e o Estado, bem como as instituições políticas modernas e, dessa forma, alteram os conceitos de cidadania e exclusão social.

Conforme exposto ao longo deste livro, cidadania e exclusão social são conceitos historicamente situados, isto é, devem ser compreendidos dentro do contexto sócio-histórico de sua época. É por esse motivo que o processo de individualização causa impacto.

Cidadania foi aqui definida como identidade social política e idealmente constituída por três elementos: vínculo de pertencimento ao Estado-Nação, possibilidade de participação política/coletiva e, por fim, posse da consciência de ser portador de direitos e deveres. As composições desses três elementos criaram uma tipologia da concepção de cidadão: cidadão politicamente passivo, cidadão isolado e cidadão pleno. A possibilidade de criar tipos de cidadania demonstra o quanto esse não é um conceito fechado e que ele é construído a partir das relações sociopolíticas, que é uma prática, um exercício e está vinculado ao Estado e sua forma de relação com sua população.

Exclusão social, terceiro conceito analisado neste livro, é processo pluridimensional que segrega e inferioriza um indivíduo ou um grupo perante sua comunidade e seu território. Os fatores que o acarretam estão nos valores dominantes da sociedade. É um estado de vulnerabilidade com níveis de maior ou menor intensidade e que percorre diversos âmbitos sociais: o econômico, o social, o biológico e o psicológico. Conforme exposto, a exclusão social não se esgota na desigualdade socioeconômica, pois são múltiplos os fatores que corroboram para que ela aconteça. A nossa definição é composta por três dimensões: precari104 zação do trabalho, precarização da sociabilidade primária 
e o estigma. A existência de uma ou duas dimensões acarreta em uma situação de vulnerabilidade, já a existência das três leva a uma situação de exclusão social. Ratifica-se aqui a importância de compreenderem-se os fatores que levam a uma dada exclusão social ou mesmo a uma situação de vulnerabilidade, pois é compreendendo as causas e atacando-as que se conseguirá alterar esse estado e, assim, efetivar a inclusão social.

Cidadania e exclusão/inclusão, conforme explicitado na apresentação, são conceitos distintos, mas complementares. Cidadania é um conceito vinculado ao Estado, enquanto que inclusão é vinculado à sociedade. Entretanto, não existe Estado sem sociedade. Dessa forma, para que exista um cidadão plenamente incluído, precede possuir as três dimensões da cidadania e não possuir as três dimensões da exclusão social. 0 que isso quer dizer? Para um cidadão ser efetivamente incluído, é necessário ser politicamente ativo, ter seus direitos devidamente assegurados, ter acesso ao mercado de trabalho, possuir vínculos sociais e não ser estigmatizado. Entretanto, o contrário também pode ocorrer: cidadãos excluídos, porém inseridos na categoria de isolados, ou mesmo cidadãos plenos, porém em situações de vulnerabilidades, seja por estarem vivendo uma determinada situação de desemprego, seja por não terem o suporte da sociabilidade primária.

Conforme referido ao longo do texto, estamos vivendo um momento histórico de transição e radicalização de paradigmas, que afetam as formas de relacionamentos, seja entre indivíduos, seja com nossas instituições sociais ou com as políticas. A compreensão do nosso mundo requer que aceitemos que alguns paradigmas modernos estejam sofrendo profundas transformações e que outros, 
como a noção de indivíduo, já foram radicalizados. É necessário um esforço analítico para aceitar que não vivemos mais num mundo estritamente moderno, conforme foi delineado naquele momento histórico de constituição da modernidade, mas que ainda temos dívidas com ela - desigualdade, cidadãos isolados, exclusão, desemprego etc. Se vivemos em um mundo mais conectado, mais tecnológico, mais consumista, mais rápido, mais global e mais diverso, ainda temos uma população sem acesso a tudo isso. Essas são as nossas dívidas para com a modernidade, cidadãos do mundo - com dupla cidadania e cidadãos isolados dentro de seu próprio Estado-Nação ou fora dele, solicitando permissão para entrar em algum Estado que os acolham, como acontece com os refugiados. São nossas contradições.

É nesse contexto que Alves (2000, p. 199), afirma que

[...] a globalização nos termos em que está posta, produz um resultado curioso: de um lado os globalizados, em qualquer sistema político gozam de todos os direitos que lhes interessa, de outro, os socialmente excluídos, providos ou desprovidos de direitos políticos, têm em teoria, quase sempre, uma cidadania política, ela não lhes proporciona, na prática, nem direitos, nem esperanças.

Podemos entender que o autor, ao falar da globalização, refere-se também às transformações sociais vividas do final do século XX para cá; são elas que provocam novos direitos, novas formas de exclusões e inclusões. É nesse interim que vivemos, num mundo desigual, com indivíduos mais solitários e vulneráveis e, portanto, necessitando de um Estado presente nas políticas sociais. 
Vivemos em um momento de incertezas, de mudanças rápidas e bruscas, difíceis de acompanhar, em que vemos nossos paradigmas, que eram nossos norteadores - emergidos na modernidade tardia -, sendo enfraquecidos e desencaixados. Eles não conseguem mais, por si só, explicar a realidade em que vivemos.

Este livro teve como objetivo discutir esses conceitos frente a essas mudanças que estamos sentindo e vivenciando, apresentando e discutindo as definições dos conceitos de individualização, cidadania e exclusão social.

Este último capítulo, portanto, não pode ser chamado de conclusão, pois ainda não se pode concluir nada, apenas problematizar e analisar o atual momento em que vivemos. Não podemos achar que tais temas estão acabados, concluídos. Assim, o título Reticências aqui tem propositadamente o objetivo de trazer essa noção de continuidade e de abertura para novos debates. 


\section{REFERÊNCIAS}

ALVES, J. A. Lindgren. Direitos humanos, cidadania e globalização. Lua Nova: Revista de Cultura e Política. São Paulo, n. 50, p. 185-206, 2000. Disponível em: <http:// www.scielo.br/scielo.php?script=sci_arttext\&pid=S0102$-64452000000200010 \& \operatorname{lng}=e n \& n r m=i s o>$. Acesso em: 2 jan. 2016.

ARENDT, Hannah. Sobre a Revolução. Apresentação: Jonathan Schell. Tradução: Denise Bottmann. São Paulo: Companhia das Letras, 2011.

A condição humana. Tradução: Roberto Raposo. Rio de Janeiro: Forense Universitária, 1999.

Origens do totalitarismo. Tradução: Roberto Raposo. São Paulo: Companhia das Letras, 1989.

ARISTÓTELES. Obras. Madeira: 2. ed. SP: Aguilar, 1973.

BACCIOTTI, Rui Carlos Duarte. Direito civil - lições preliminares. 2002. Disponível em: <http://www.egov.ufsc. br/portal/sites/default/files/anexos/22619-226211-PB.htm>. Acesso em: 19 mai. 2015. 
BAUMAN, Zygmunt. Vida líquida. Rio de Janeiro: Zahar, 2005a.

Identidade. Rio de Janeiro: Zahar, 2005b.

. Vidas desperdiçadas. Rio de Janeiro: Zahar, 2005c.

Amor Líquido. Sobre as fragilidades dos laços humanos. Rio de Janeiro: Zahar, 2004.

. Modernidade líquida. Rio de Janeiro: Zahar, 2001.

. Modernidade e Ambivalência. Rio de Janeiro: Zahar, 1999a.

. Globalização: as consequências humanas. Tradução: Marcus Penchel. Rio de Janeiro: Zahar, 1999b.

. 0 mal-estar da pós-modernidade. Rio de Janeiro: Zahar, 1998.

BECK, Ulrich. Sociedade de risco: rumo a uma outra modernidade. São Paulo: Ed. 34, 2011.

. A reinvenção da política: rumo a uma teoria da modernidade reflexiva. In: GIDDENS, Anthony; BECK, Ulrich; LASH, Scott. Modernidade reflexiva - Política, tradição e estética da ordem social moderna. São Paulo: Unesp, 1997.

BENEVIDES, Maria Victoria de Mesquita. Cidadania e democracia. Lua Nova: Revista de Cultura e Política, n. 33, p. 5-16, 1994. ISSN 0102-6445. Disponível em: <http:// dx.doi.org/10.1590/S0102-64451994000200002>. Acesso em: 25 set. 2017. 
BOBBIO, Norberto et al. Dicionário de Política. 12. ed., v. 2. Brasília: UnB, 1999.

BOBBIO, Norberto. A era dos direitos. Rio de Janeiro: Elsevier, 2004.

Estado, governo sociedade. Para uma teoria geral da política. Rio de Janeiro: Paz e Terra, 1987.

BONAVIDES, Paulo. Curso de Direito Constitucional. 18 ed. São Paulo: Malheiros Editores, 2006.

BOTELHO, A.; SCHWARCZ, L. M. Introdução - Cidadania e direitos: aproximações e relações. In: BOTELHO, A.; SCHWARCZ, L. M. (Org.). Cidadania, um projeto em construção: minorias, justiça e direitos. São Paulo: Claro Enigma, 2012.

CAMPOS, André et al. Atlas da exclusão social no Brasil. Volume 2. Dinâmica e manifestação territorial. São Paulo: Cortez, 2003.

CARNOY, Martin. Estado e Teoria Política. Campinas: Papirus, 1988.

CARVALHO, José Murilo de. Cidadania no Brasil: o longo caminho. 19. ed. Rio de Janeiro: Civilização Brasileira, 2015.

Desenvolvimento de la cidadania en Brasil. México: Fondo de Cultura Económica, 1995.

CARVALHO, Maria do Carmo Brant de (Org.) A família contemporânea em debate. São Paulo: Cortez, 2000. 
CARVALHO, Sérgio Resende. Conexões Saúde Coletiva e Políticas de Subjetividade. São Paulo: Hucitec, 2009.

CASTEL, Robert. As armadilhas da exclusão. In: WANDERLEY, Mariângela Belfiore et al (Org.). Desigualdade e a questão social. São Paulo: EUC, 2000.

As metamorfoses da questão social: uma crônica do salário. Petropolis, RJ: Vozes, 1998a.

. Rupturas irremediáveis: sobre Tristão e Isolda. Lua Nova: Revista de Cultura e Política. Sujeito e Objeto, n. 43. São Paulo: Cedec, quadrimestral, 1998b. p. 171-188.

A dinâmica dos processos de marginalização: da vulnerabilidade à "desfiliação". Caderno CRH, Salvador, n. 26/27, p. 19-40, jan./dez. 1997. Disponível em: <http:// www.cadernocrh.ufba.br/viewarticle.php?id=193>. Acesso em: 13 set. 2015 .

. Da indigência à exclusão, a desfiliação: precariedade do trabalho e vulnerabilidade relacional. In: LANCETTI, Antonio (Org.). Saudeloucura, v. 4: grupos e coletivos. São Paulo: Hucitec, 1994. p. 21-48.

CASTELLS, Manuel. 0 poder da identidade - $\mathrm{A}$ era da informação: economia, sociedade e cultura. Volume 2. São Paulo: Paz e Terra, 2000.

. Sociedade em rede - A era da informação: economia, sociedade e cultura. Volume 1. São Paulo: Paz e Terra, 1999a. 
. Fim do Milênio - A era da informação: economia, sociedade e cultura. Volume 3. São Paulo: Paz e Terra, 1999b.

CHAUÍ, Marilena. Cultura e democracia. São Paulo: Moderna, 1984.

CLAVEL, Gilbert. A sociedade da exclusão: compreendê-la e dela sair. Portugal: Ed. Porto, 2012.

COELHO JUNIOR, Nelson; SALEM, Pedro; KLAUTAU, Pela (Org.) Dimensões da intersubjetividade. Alter - Revista de Estudos Psicanalíticos, v. 30 (1), p. 135-138. São Paulo: Escuta/Fapesp, 2012.

CONSTANT, Benjamin. Da liberdade dos antigos comparada à dos modernos. Revista Filosofia Política, Porto Alegre, n. 2, p. 9-75, 1985.

DALLARI, Dalmo de Abreu. Elementos de Teoria Geral do Estado. São Paulo: Saraiva, 2001.

DE MARTINO, Mónica Solange. Politicas Sociales y Família: Estado de Bienestar y Neoliberalismo Familiarista. Fronteiras, Montevidéu, Uruguay, n. 4, p. 101-114, 2001.

DUPAS, Gilberto. A lógica da economia global e a exclusão social. Estud. av., vol. 12, n. 34, p. 121-159. São Paulo set./dez. 1998. ISSN 1806-9592. Disponível em: <http:// dx.doi.org/10.1590/S0103-40141998000300019>. Acesso em: 22 jun. 2015.

ESCOREL, Sarah. Exclusão social. Dicionário da educação profissional em saúde. Fundação Oswaldo Cruz, 
2009. Disponível em: <http://www.epsjv.fiocruz.br/ dicionario/verbetes/excsoc.html . Acesso em: 22 jun. 2015.

ESTIVILL, Jordi. Panorama da luta contra a exclusão social. Conceitos e estratégias. Genebra: Bureau Internacional do Trabalho, Programa Estratégias e Técnicas contra a Exclusão Social e a Pobreza, 2003.

FERREIRA, Gabriela Nunes; FERNANDES, Maria Fernanda Lombardi. Cidadão e Cidadania. In: GIOVANNI, Geraldo Di; NOGUEIRA, Marco Aurélio (Org.). Dicionário de Políticas Públicas. Volume 2. São Paulo: Fundap - Imprensa Oficial do Estado de São Paulo, 2013.

FLEURY, Sonia. Pobreza, desigualdades ou exclusão? Ciência \& Saúde Coletiva, 2007, vol. 12, n. 6, p. 14221425. ISSN 1678-4561. Disponível em: <http://dx.doi. org/10.1590/S1413-81232007000600003>. Acesso em: 5 jul. 2014.

GIDDENS, Anthony. Mundo em descontrole: o que a globalização está fazendo de nós. Tradução: Maria Luiza Borges. Rio de Janeiro: Record, 2005.

. Modernidade e identidade. Tradução: Plínio Dentzien. Rio de Janeiro: Zahar, 2002.

As consequências da pós-modernidade. São Paulo: Unesp, 1991.

GIDDENS, Anthony. A vida em uma sociedade Pós-Tradicional. In: BECK, U.; GIDDENS, A.; LASH, S. (Org.). 
Modernização reflexiva: política, tradição e estética na ordem social moderna. São Paulo: Editora Unesp, 1997.

GIL, Antonio Carlos. Como elaborar projetos de pesquisa. 5. ed. São Paulo: Atlas, 2008.

GOFFMAN, Erving. Estigma. Notas sobre a manipulação da identidade deteriorada. Rio de Janeiro: Zahar, 1978.

GOHN, Maria da Glória. Abordagens teóricas no estudo dos movimentos sociais na América Latina. Caderno CRH, Salvador, v. 21, n. 54, p. 439-455, dec. 2008. Disponível em: <http://www.scielo.br/scielo.php?script=sci_ arttext\&pid=S0103-49792008000300003\&lng=en\&nrm =iso>. Acesso em: 22 ago. 2015.

GOMES, Orlando. Introdução ao direito civil. Coordenador: Edvaldo Brito. 19. ed. Rio de Janeiro: Forense, 2007.

GOSS, K. P; PRUDENCIO, K. O conceito de movimentos sociais revisitado. Revista Eletrônica dos Pós-Graduandos em Sociologia Política da UFSC, vol. 2, n. 1, janeiro-julho 2004. p. 75-91.

GRAMSCI, Antônio. Os intelectuais e a organização da cultura. Tradução: Carlos Nelson Coutinho. 4. ed. Rio de Janeiro: Editora Civilização Brasileira S.A., 1976.

Maquiavel, a Política e o Estado Moderno. RJ: Editora Civilização Brasileira S.A., 1968.

GUATTARI, Felix; ROLNIK, Suely. Micropolítica: cartografias do desejo. 7. ed. Petrópolis: Vozes, 2005. 
HABERMAS, Jürgen. A inclusão do outro. Estudos de teoria política. São Paulo: Ed. Loyola, 2002.

. Citizenship and a National Identity. In: Bart van Steenbergen (Ed.). The Condition of Citizenship. London: Sage Publications, 1994. p. 20-35.

HARVEY, David. Condição pós-moderna: uma pesquisa sobre as origens da mudança cultural. Tradução: Adail Ubirajara e Maria Stela Gonçalvez. Rio de Janeiro: Loyola, 1994.

HOBBES, Thomas. Leviatã ou matéria, forma e poder de um estado eclesiástico e civil. Coleção Os pensadores, vol. XV. Tradução: João Paulo Monteiro e Maria Beatriz Nizza da Silva. São Paulo: Nova Cultural, 1999.

HOLANDA, Aurélio Buarque de. Dicionário Aurélio da Língua Portuguesa. 5. ed. São Paulo: Editora Positivo, 2010.

IANNI, Aurea Maria Zöllner. Mudanças Sociais Contemporâneas e Saúde: considerações sobre a Biomedicina e a Saúde Pública. Ideias - Revista do Instituto de Filosofia e Ciências Humanas da Unicamp, v. 6, p. 41-58, 2013. Disponível em: <http://www.ifch.unicamp.br/ojs/index.php/ ideias/article/view/1392/966>. Acesso em: 13 out. 2015.

et al. As Ciências Sociais e Humanas em Saúde na Abrasco: a construção de um pensamento social em saúde. Cad. Saúde Pública, Rio de Janeiro, v. 30, n. 11, p. 22982308, nov. 2014. Disponível em: <http://www.scielo.br/ 
scielo.php?script=sci_arttext\&pid=S0102-311X20140011 02298\&lng=en\&nrm=iso $>$. Acesso em: 1 nov. 2015.

IANNI, Octavio. A sociedade global. Rio de Janeiro: Civilização Brasileira, 1997.

. Teorias da Globalização. Rio de Janeiro: Civilização Brasileira, 2003.

KOWARICK, Lúcio. Sobre a vulnerabilidade socioeconômica e civil: EUA, França e Brasil. Revista Brasileira de Ciências Sociais. São Paulo, n. 51, vol. 18, fev. 2003.

. Viver em risco - sobre a vulnerabilidade no Brasil urbano. Novos Estudos, n. 63, vol. 2, São Paulo, jul. 2002.

LAFER, Celso. A reconstrução dos direitos humanos: um diálogo com o pensamento de Hannah Arendt. São Paulo: Companhia das Letras, 1988.

LASH, Christopher. A cultura do Narcisismo: a vida americana numa era de espaço em declínio. Rio de Janeiro: Imago, 1983.

LENOIR, Rene. Les exclus: un français sur dix. Paris: Seuil, 1989.

LIPOVETSKY, Gilles. A era do vazio: ensaio sobre o individualismo contemporâneo. Tradução: Miguel Serras Pereira e Ana Luísa Faria. Barueri: Ed Manole, 2005a.

A sociedade pós-moralista: o crepúsculo do dever e a ética indolor dos novos tempos democráticos. São Paulo: Manole, 2005b. 
. Os tempos hipermodernos. Tradução: Mário Vilela. São Paulo: Barcarolla, 2004.

LOCKE, Jhon. Segundo Tratado Sobre o Governo. Tradução: Alex Marins. São Paulo: Ed. Martim Claret, 2006.

LYOTARD, Jean-François. A condição pós-moderna. São Paulo: José Olympio, 2002.

MARSHALL, Thomas. Cidadania, classes e status. Rio de Janeiro: Zahar, 1967.

MATEUS, Samuel. O Indivíduo pensado como Forma de Individuação. Estudos em Comunicação, n. 10, p. 93-106, 2011.

MIRANDA, Francisco Cavalcanti Pontes de. Tratado de Direito Privado. Parte Geral, Tomo I, Introdução. Pessoa física e jurídica. 2. ed. Rio de Janeiro: Borsoi, 1954.

NOGUEIRA, Marco Aurélio. Estado - verbete. In: DI GIOVANNI, Geraldo; NOGUEIRA, Marco Aurélio (Org.). Dicionário de Políticas Públicas. 1. ed., v. 1, São Paulo: FUNDAP/Imprensa Oficial, 2013. p. 334-343.

. Em defesa da política. São Paulo: Ed. Senac, 2001. . Cidadania, crise e reforma democrática do Estado. Perspectivas, São Paulo, v. 22, p. 61-84, 1999.

ORGANIZAÇÃO DAS NAÇÕES UNIDAS (ONU). Declaração universal dos direitos humanos. Assembleia Geral das Nações Unidas em Paris. 10 dez. 1948. Disponível 
em: <http://www.onu.org.br/img/2014/09/DUDH.pdf>. Acesso em: 2 jun. 2017.

ORGANIZACIÓN INTERNACIONAL DE TRABAJO (OIT) e Organización Panamericana de la Salud (OPS). Panorama de la exclusión de la protección social en salud en América Latina y el Caribe. Reunión tripartita de la OIT con la colaboración de la OPS. Extensión de la protección social en salud a los grupos excluidos en América Latina y el Caribe. Washington D.C.: OIT, OPS/OMS, 1999.

PAUGAM, Serge. A desqualificação social: ensaio sobre a nova pobreza. Portugal: Ed. Porto, 2006.

. Pobreza, exclusão e desqualificação social: resumindo o debate europeu. In: VERAS, Maura Pardini Bicudu; SPOSATI, Aldaiza; KOWARICK, Lucio. Por uma sociologia da exclusão social: o debate com Serge Paugam. São Paulo: Educ, 1999. p. 116-119.

PELBART, Peter Pál. Biopolítica e biopotência no coração do Império. In: GADELHA, S.; LINS, D. (Org.). Nietzsche e Deleuze: que pode o corpo? Rio de Janeiro: Relume Dumará, 2002. p. 251-260.

PEREIRA, Luiz Carlos Bresser. A reforma do Estado dos anos 90: lógica e mecanismo de controle. Revista Lua Nova, n. 45, Cedec, 1998. p. 49-95.

PERUCCHI, Juliana; BEIRAO, Aline Maiochi. Novos arranjos familiares: paternidade, parentalidade e relações de gênero sob o olhar de mulheres chefes de família. Psicologia clínica, vol. 19, n. 2, p. 57-69, RJ, 2007. 
Disponível em: <http://www.scielo.br/scielo.php? script $=$ sci_arttext\&pid $=$ S0103-56652007000200005\&ln $\mathrm{g}=\mathrm{en} \& \mathrm{nrm}=\mathrm{iso}>$. Acesso em: 29 jul. 2015.

PIOVESAN, Armando; TEMPORINI, Edméa Rita. Pesquisa exploratória: procedimento metodológico para o estudo de fatores humanos no campo da saúde pública. Saúde Pública, vol. 29, n. 4, p. 318-325, 1995. Disponível em: <http://www.scielo.br/scielo.php?pid=S0034$-89101995000400010 \&$ script $=$ sci_abstract $\&$ tlng $=p t>$. Acesso em: 26 set. 2017.

ROUANET, Sérgio Paulo. As razões do iluminismo. São Paulo: Companhia das Letras, 1992.

ROUSSEAU, Jaques. Do contrato social. Coleção Os Pensadores. Tradução: Lourdes Santos Machado. São Paulo: Nova Cultural, 1999.

SAES, Décio Azevedo Marques de. A questão da evolução da cidadania política no Brasil. In: Estudos Avançados, vol. 15, n. 42, São Paulo, 2001. Disponível em: <http://www.scielo.br/scielo.php?script=sci_arttext\&pid $=$ S0103-40142001000200021 >. Acesso em: 26 set. 2017.

SALVADOR, Ângelo Domingos. Métodos e técnicas de pesquisa bibliográfica. Porto Alegre: Sulina, 1971.

SANTOS, Boaventura de Souza. Modernidade, identidade e a cultura de fronteiras. Revista Critica de Ciências Sociais, n. 38, Coimbra, Portugal, dez. 1993. p. 11-29.

SAWAIA, Bader (Org.). As artimanhas da exclusão: análise psicossocial e ética da desigualdade social. Petrópolis:

120 Vozes, 2001. 
SCARCELLI, Ianni Regia. Entre o hospício e a cidade - Dilemas no campo da saúde mental. São Paulo: Ed. Zagodoni, 2011.

SECCHI, Leonardo. Políticas públicas - conceitos, esquemas de análise, casos práticos. 2. ed. São Paulo: Cengage Learning, 2014.

SILVA, Glauce Cerqueira Correa da; SANTOS, Luciana Mateus; TEIXEIRA, Luciane Alves et al. A mulher e sua posição na sociedade - da antiguidade aos dias atuais. Rev. SBPH, vol. 8, n. 2, Belo Horizontes - MG, dez, 2005.

SPOSATI, A. Exclusão social abaixo da linha do equador. In: VERAS, Maura Pardini Bicudu; SPOSATI, Aldaiza; KOWARICK, Lucio. Por uma sociologia da exclusão social: o debate com Serge Paugam. São Paulo: Educ, 1999. p. $128-133$.

SUBIRATS, Joan. Nuevos tiempos, ¿nuevas políticas públicas? Explorando caminos de respuesta. Revista del CLAD Reforma y Democracia, n. 54, Caracas, out. 2012.

TEIXEIRA, Elenaldo Celso. 0 local e o global: limites e desafios da participação cidadã. São Paulo: Cortez; 2001.

TOURAINE, Alan. Crítica da modernidade. Petrópolis: Vozes, 1995.

VÉRAS, Maura Pardini Bicudu. Exclusão social - um problema de 500 anos. In: SAWAIA, Bader (Org.). As artimanhas da exclusão: análise psicossocial e ética da desigualdade social. Petrópolis: Vozes, 2001. p. 27-46. 
VILLA, Simone Barbosa. Os formatos familiares contemporâneos: transformações demográficas. Observatorium: Revista Eletrônica de Geografia, v. 4, n. 12, p. 2-26, Uberlândia, dez. 2012.

VIEIRA, Liszt. Cidadania e globalização. Rio de Janeiro: Record, 2013.

WANDERLEY, Mariangela Belfiore. Refletindo sobre a noção de exclusão. In: SAWAIA, Bader (Org.). As artimanhas da exclusão: análise psicossocial e ética da desigualdade social. Petrópolis: Vozes, 2001. p. 19-23.

WEBER, Max. Ciência e Política: duas vocações. São Paulo: Cultrix, 1998.

ZIONI, Fabiola. Exclusão social: noção ou conceito? Saúde soc., v. 15, n. 3, p. 15-29, São Paulo, dec. 2006. Disponível em: <http://www.scielo.br/scielo.php?script=sci_ arttext\&pid=S0104-12902006000300003\&lng=en\&nrm =iso>. Acesso em: 31 out. 2012. 